Rakenteiden Mekaniikka (Journal of Structural Mechanics)

Vol. 51, No 2, 2018, pp. 1-31

https://rakenteidenmekaniikka.journal.fi/index

https://doi.org/10.23998/rm. 69735

(C) The author(s) 2018.

Open access under CC BY-SA 4.0 license.

\title{
History of structural analysis \& dynamics of Wärtsilä medium speed engines
}

\author{
Tero Frondelius ${ }^{1}$, Hannu Tienhaara and Mauri Haataja
}

Summary. This paper opens up the history of structural analysis and dynamics simulations of Wärtsilä engines. It cites already published articles and theses with some backgrounds information. It also discusses some of the backgrounds of the in-house tool development. Additionally, this paper presents the development of the computers and investment of the simulation capacity in order to understand how it has been the enabler of ever more complicated models. It lists the work done during fifty decades. The authors sincerely attempt to make this article as readerfriendly as possible, even though there are over 220 references, which of course demonstrates how dedicated Wärtsilä has been in supporting numerical simulations research in the past five decades.

Key words: Wärtsilä, finite element method, FEM, history of engine development, history of strength calculations

Received 26 February 2018. Accepted 6 July 2018. Published online 8 December 2018

\section{Introduction}

Based on the feedback the authors have received it seems that the audience is very interested in finding out more about the history of the Finnish Structural Mechanics in the industry. Liljenfeldt's article Computers in diesel engine development [1] from the year 1992 served as a good starting point for this paper. The authors recommend it for the history enthusiast of computer-aided engineering. Hagelsberg's article Sinapinsiemen kylvetään [2] is also innovative, and despite the name it is describes the history of engine design. Hagelsberg was the head of the simulation team up until 1976, when Liljenfeldt took the position.

This paper outlines the history of simulation methods developed in the Wärtsilä fourstroke engine Research and Development, see Table 1 for some milestones. This paper can be used in the new employee induction process to familiarize them with the history of the used simulation methodologies. In addition, professors can use this paper in university education to teach next generation engine builders and research engineers about the research and method development of the modern $R \& D$ organization.

\footnotetext{
${ }^{1}$ Corresponding author. tero.frondelius@wartsila.com
} 

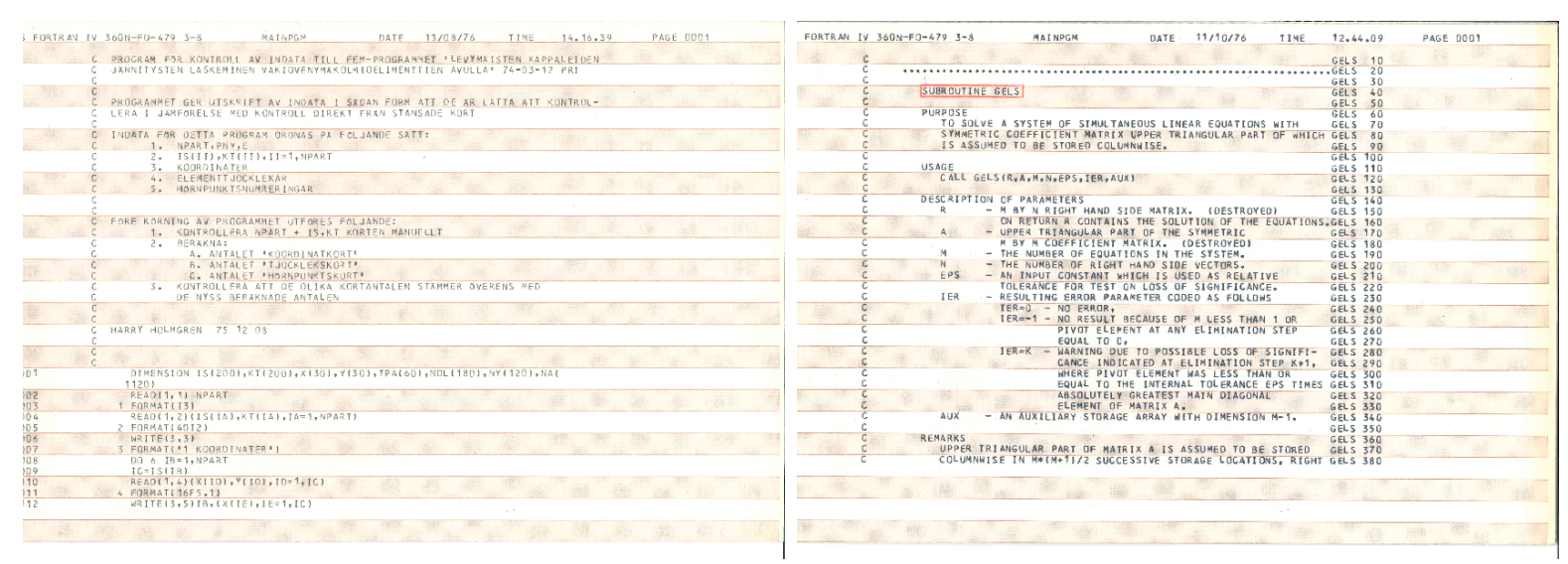

Figure 1. One version of Pentti Rajamäki's coded first Finite Element Method (FEM)
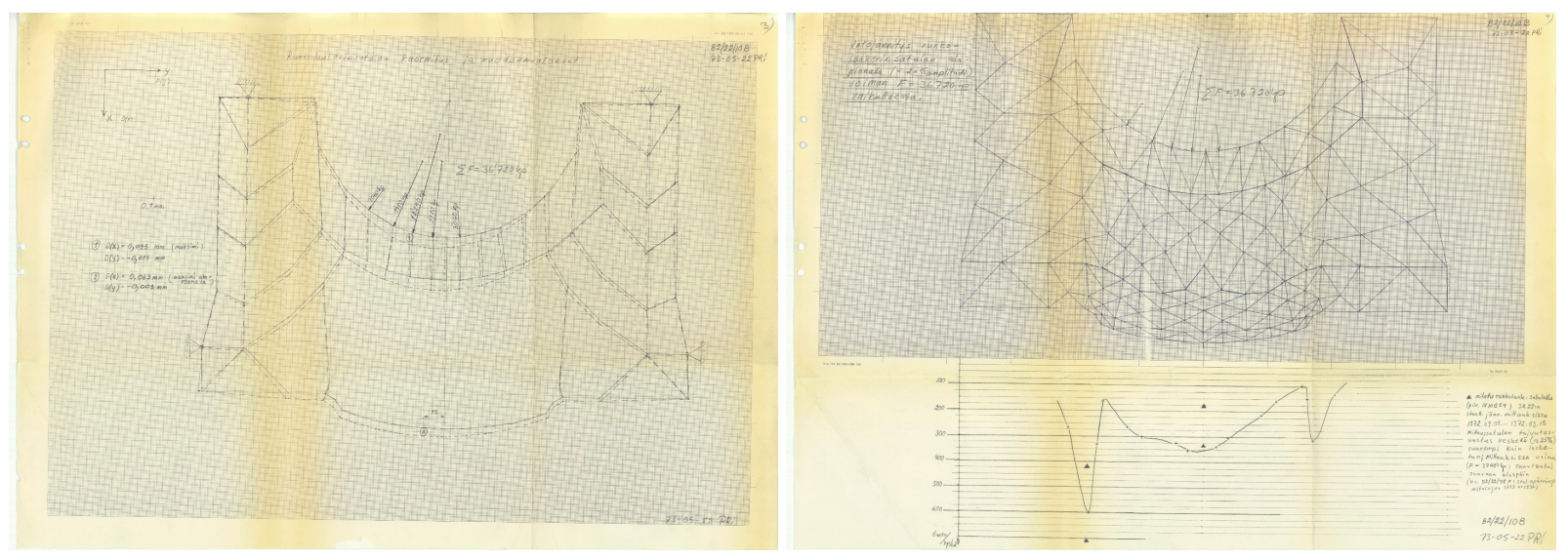

Figure 2. Vasa 22 main bearing cap 1973: Loading, deformation, and measurements [3]

The authors wanted to take a scientific approach and write this paper based on the published results. This way it will work as a future index for looking at previous research work about structural simulations of Wärtsilä engines. This paper is mainly written in a chronological order and divided in sections representing different decades. Due to a high number of references, all of them are collected under bigger umbrellas, to keep the storyline more readable and less fractioned. Some of the fascinating details or exceptional achievements will be highlighted to make the story more interesting to read. This paper is a scientific review of simulation method development work from the past five decades.

Writing this paper was unquestionably an exciting experience and can be recommended to all our colleagues in the industry. It is worthy to go through the history before "blindly" heading towards the future. As a reader, please take this as a challenge and write the history now, when it is still fresh in our memories. The future generation of engineering mechanics experts will surely appreciate the effort. These history articles will be used both internally in the company as an index of research, and externally in the universities as a helpful introduction for specifying the simulation needs of industry.

\section{Starting from the seventies and continuing in the eighties}

In the early seventies, Structural Analysts performed strength calculations with a pen, paper and slide rules, and towards the end of the decade, slide rules were little by little replaced by pocket calculators. Interestingly, the same engine components as today were 


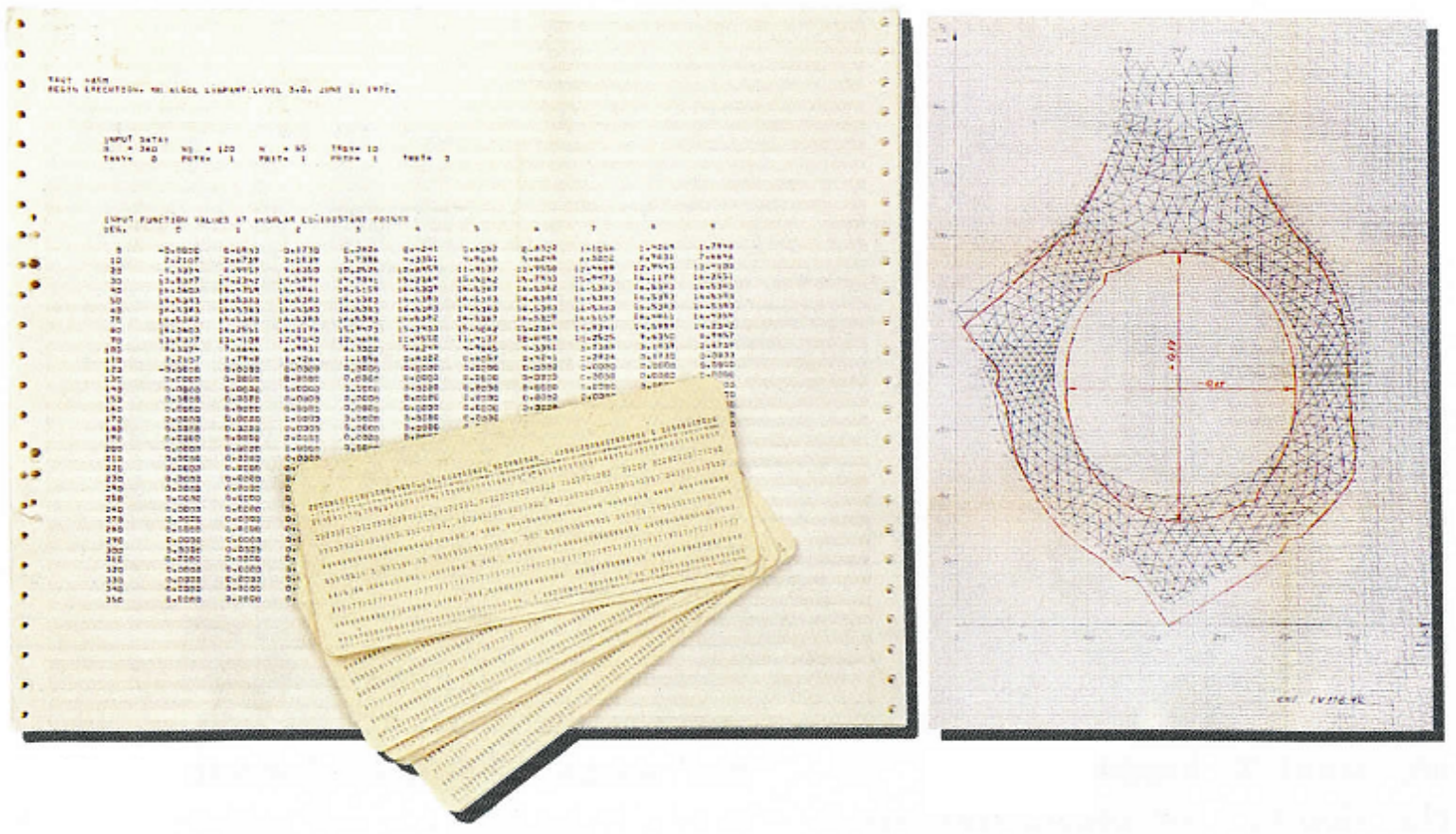

Figure 3. Vasa 32 connecting rod 1975: Numerical stress and displacement results on paper, drawn on a picture by hand. [1]

the target of the simulations [5-8] including connecting rod, fuel pump, piston, crankshaft and cylinder liner.

The first numerical simulation in Wärsilä was Gösta Liljenfeldt's master thesis about fuel pump cavitation [6]. Pentti Rajamäki developed the first internal Finite Element Method (FEM) solver in the year 1970 [2], see Figure 1, by using the first edition of the Zienkiewich's book The finite element method, which was published 1967, and remained the only book about FEM until 1971 [9]. The FEM was taken into the production calculation usage quite quickly, as one can see from several documents. For example, Figures 2 and 3 show the usage of the solver. Triangular plane stress and plane strain elements enabled the analyst to study "complex" plane structures exposed to nodal forces. The means of varying the element thicknesses were considered the third dimension. Structural analysts had to walk to the Hartman building next to the marketplace in Vaasa, where they ran the analyses on Tietobotnia's IBM computer. Bookkeeping used the same IBM computer for salary counting, but then the common business-oriented language (COBOL) was used. They used a fairly small amount of nodes and elements for practical reasons. No computerized pre- and post-processing software or hardware was available. The structural analysts had to plot meshes and nodal displacements by hand, which was a very time-consuming task. Stresses could not be presented graphically with any reasonable amount of effort. Thus, they were read from numerical lists element by element, see Figure 3.

Wärtsilä Vasa Factory acquired its first computer in the late 1970s. The intention was to use this HP1000 minicomputer for laboratory and production test bench measurements, as well as monitoring purposes on the test bench. The core size was 32 kilowords, or 64 $\mathrm{kb}$. Discs were not available; the structural analysts had to use the only mass storage device, which was a tape reader and punch device, used for both input and output. A FORTRAN compiler was available, and when a copy of a commercial FE-software SAP 

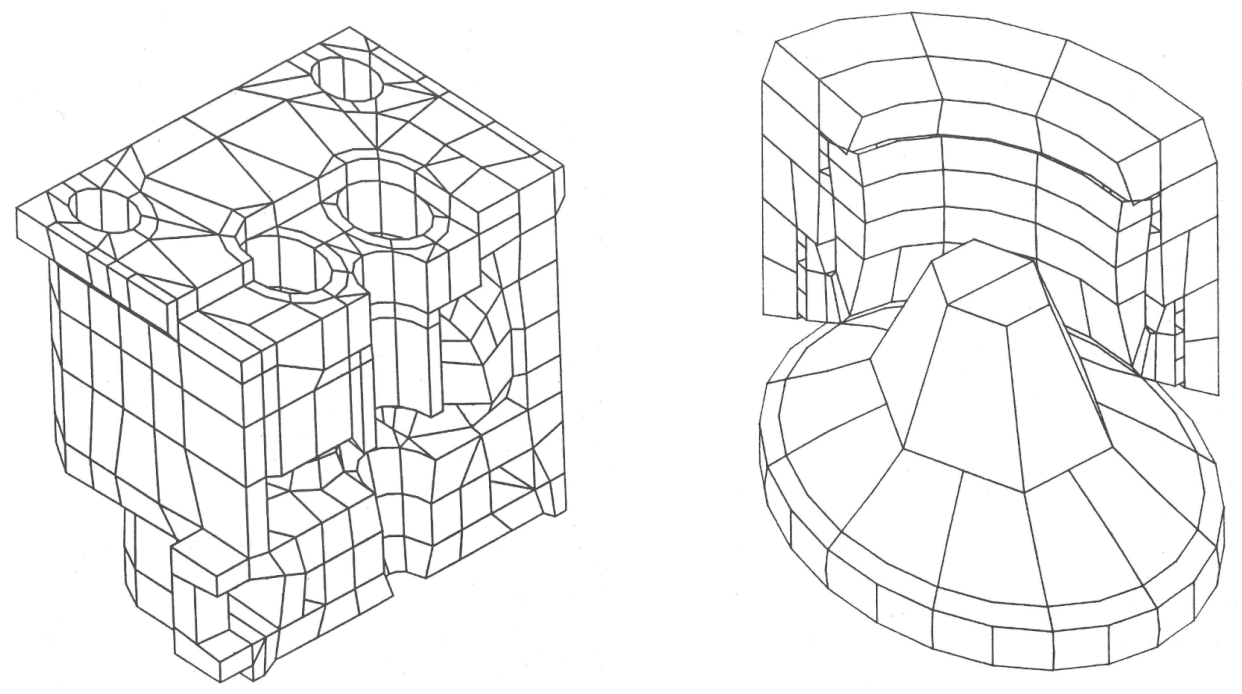

Figure 4. W22HF cylinder head calculation 1982 [4]

"was found on the market", it was installed and used. Its routines enabled us to carry out an FE analysis with more advanced element types such as quadratic plane stress and strain domains. Mesh size was still limited to a few hundred degrees of freedom. When Wärtsilä bought and installed a disc package with a capacity of a few $100 \mathrm{MBs}$ in approximately 1980, the mesh size grew to at least 1000 degrees of freedom. The chicken and egg race started: more storage capacity and more powerful computers allowed us to use more accurate models, and in turn more accurate models asked for more and more storage capacity and power. See Figure 6. [10]

The very first commercial FEM usage was Harry Holmgren's Stardyne FEM course project work, see Figure 5, where he calculated the Vaasa 32 main bearing cap [11]. This was also the first published Finite Element Analysis (FEA) [12], see the Figures 7(a), 7(b), 7(c), 7(d), 7(e) and 7(f). Adina was the first commercial FEM code purchased to Wärtsilä. The reasoning behind the selection was a good experience from SAP, whose principal developer Dr. Klaus-Jürgen Bathe started the development of Adina.

The second published FEA was Sjölind's master's thesis [13] on cylinder liner thermoelastic deformations 3D elements. However, the story behind the cooperation is a little bit bouncy. According to [14], Stig waited for boundary conditions for over one year in Vaasa. For one reason or another, he never got the needed boundary conditions from component experts, and left for Oulu with a never look back, and burn the bridges attitude. Nevertheless, he finalized the thesis, and it remains the second published FEA of Wärtsilä products. On the topic of master's theses and numerical computation development, the cylinder head has probably been the component that has benefited the most from the development of FEM. The earliest cylinder head FEA in Wärtsilä was performed already in 1983 [4], see Figure 11. Additionally, the piston FEA was performed three years later in 1986 [15].

At a very early stage, Wärtsilä focused on the engine dynamics [16-19] and their impact on the fundamentals. One of the early tasks of Adina FEM program, actually a test case, was to test its shell elements. The simulation manager selected the common base frame as the test case. An interesting detail was that there were some problems with bad element quality, and as a result, the Adina simulation crashed. Therefore, the analyst decided to make a queue of different versions of the mesh to debug the problem faster. 


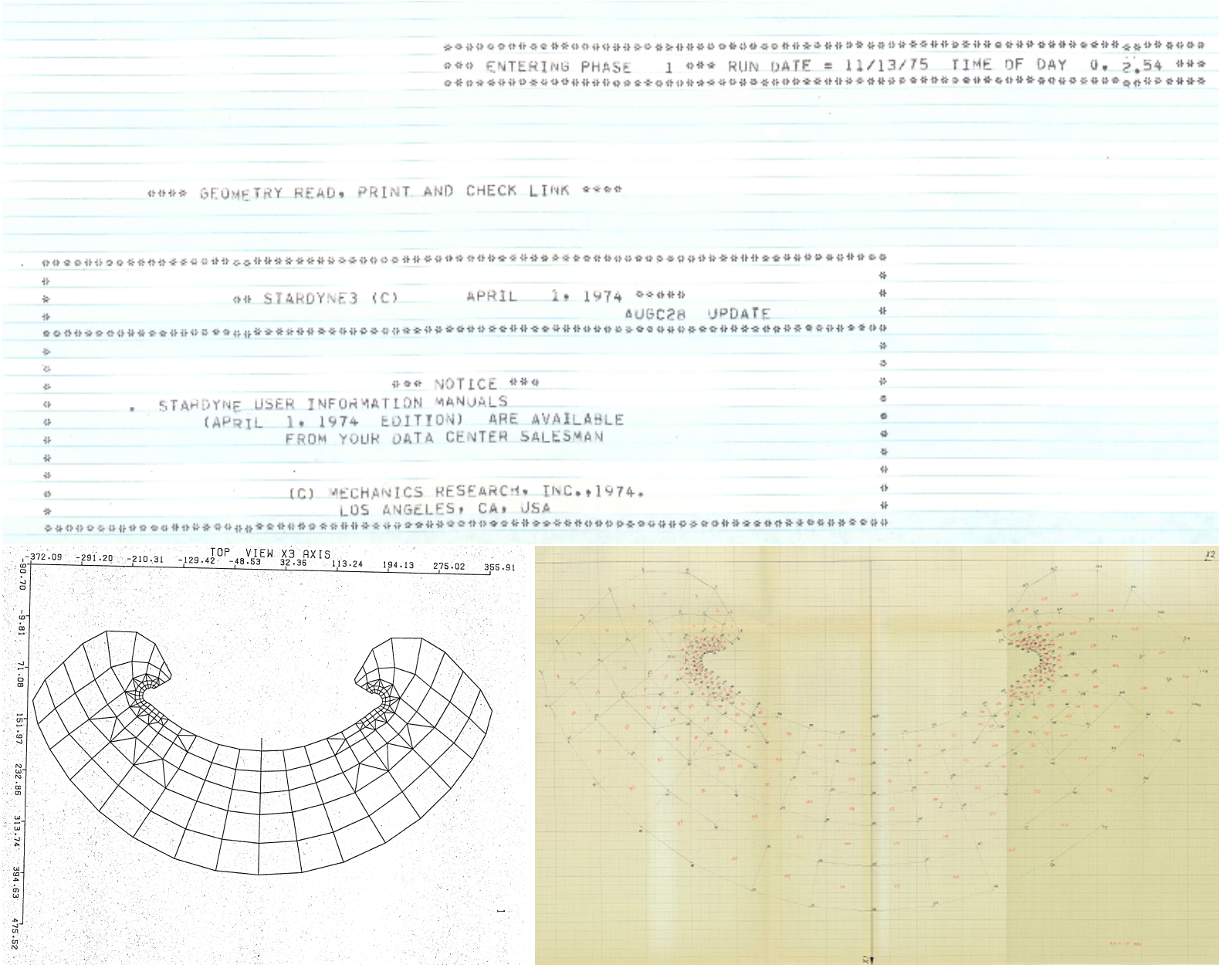

Figure 5. Main Bearing Cap calculation using Stardyne 3.0

However, this lead to the situation where all the server resources were "stolen" to the Research and Simulation team, which made the design team very unhappy because they used the same server for CAD work at the time. [10] What is most interesting about this is the fact that humans have not changed, even today with the "unlimited" server resources compared to those in the late eighties. However, some individual analysts can still steal all the resources to themselves, even with the same basic trick of simply generating a lot of simulations tasks to the queue.

Usually, behind all simulation tasks there is a real need for the results. Another example of the common base frame dynamics simulations is Rabb's master thesis [17], which was initiated by a field vibrations problem of twelve delivered 18-cylinder vee engines of Vasa 32 type. These aggregates had enormous vibrations issues, and the customer was already at a point where the only outcome is the cancellation of the order, in other words, he was willing to return the nonworking aggregates to Vaasa. Rabb, together with his colleague Martikainen did considerable work calculating different field fix options. Finally, it was discovered that the solutions was to add a bottom plate to the aggregates, which of course at this point was not a very attractive solution from the welder point of view. [10]

The work was only halfway when the technically feasible solution had been found to fix the problem. Next, someone needed to go and visit the angry customer and explain the somewhat technical problem. Liljenfeldt was assigned the job to go around the world and meet the customer. The customer was not convinced, and he wanted to bring his 


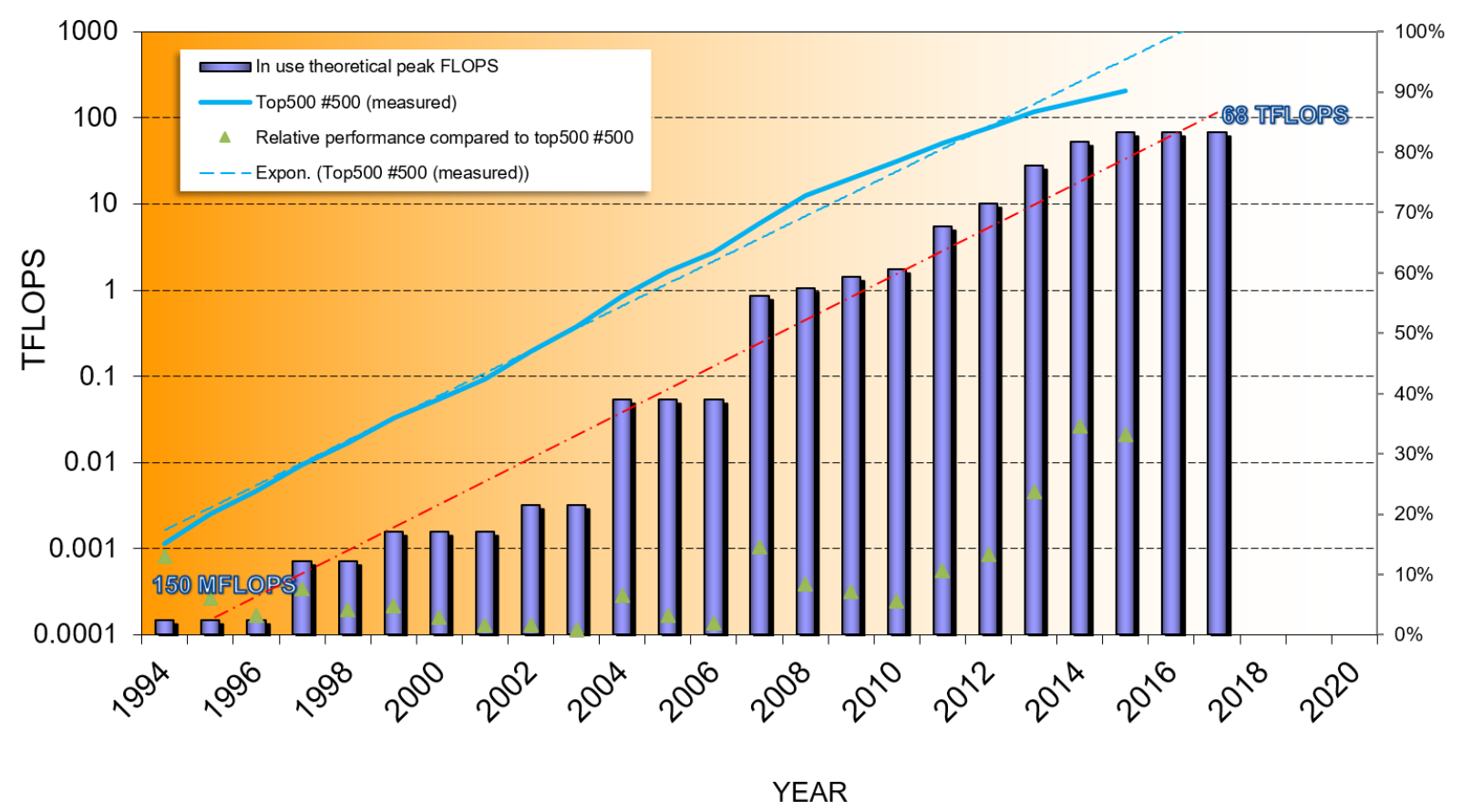

Figure 6. Computing capacity development 1994-2017

expert Ph.D. for the meeting the following day. The expert was not convinced with the idea of finite element computations and stood his ground about how it is possible to solve these sizes matrices by hand. Liljenfeldt tried his best to convince the expert about the fact that this is the solution, we trust our simulation model and this change will fix the issue. At dinner, the customer gave partly in after revealing that their expert was a Ph.D. in history, and promised Wärtsilä to try their best with one aggregate. However, he demanded that Liljenfeldt stay and wait for these modifications to happen. Of course, this was not possible, it was Liljenfeldt's summer vacation, and he left back home to Finland. After the summer vacation, a letter was waiting from a genuinely angry customer who had already contacted Wärtsilä CEO about the poor customer assistance he had gotten from Liljenfeldt earlier. However, the story had a happy ending, as after the modification, a comparison of a simulated and measured model showed that the correlation was excellent. This meant that the simulated model was quite exact compared to the measurements. Of course, this led to the situation where customer satisfaction was up again. The customer even ordered five more aggregates after the problem was solved. [10]

Another way that Wärtsilä has been building customer trust in numerical computations is the active contribution in CIMAC Congresses. For example, in the year 1985 Ahlqvist et al. [20] presented a CAD-enabled design process, and in the year 1987 Paro et al. presented the effect of compression ratio to the durability of the crankshaft [21], which is the key design question in engine concepts. Another interesting CIMAC contribution is the paper about the piston fatigue analysis from 1987 by Silvonen et al. [22]. On the topic of pistons reliability, Wärtsilä's supplier also published relevant results, see [23]. 

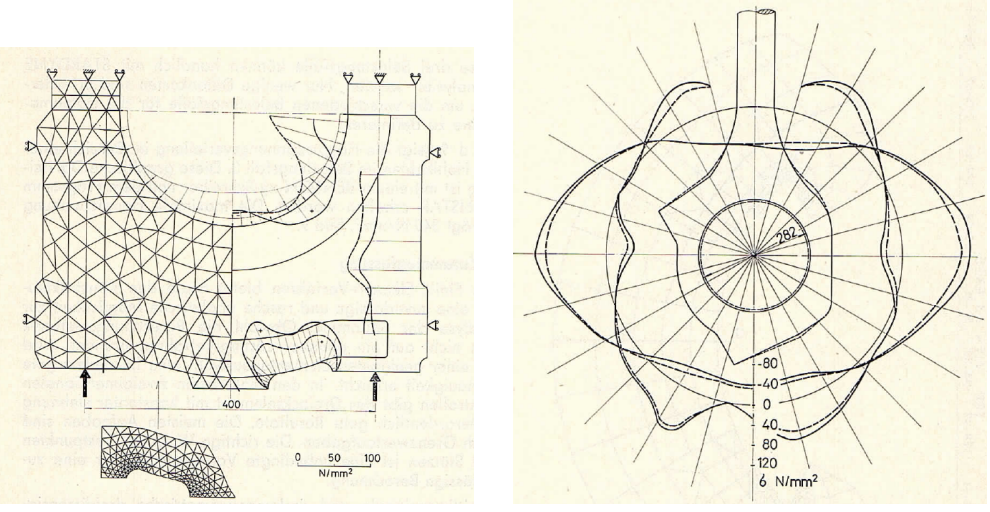

(a) Main Bearing Cap, FEM (b) Connecting Rod deformamesh and bending stress in some tions cut sections

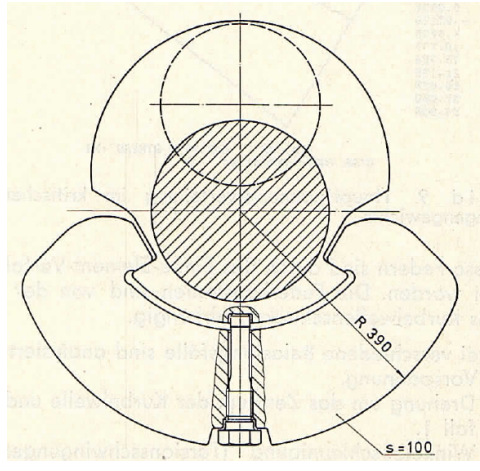

(d) Counterweight drawing

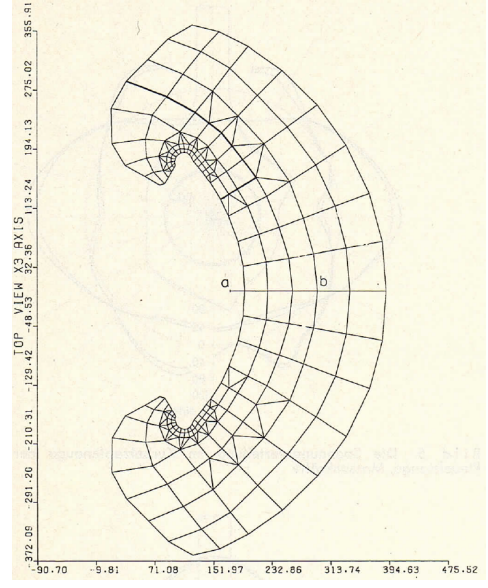

(e) Counterweight FEM mesh

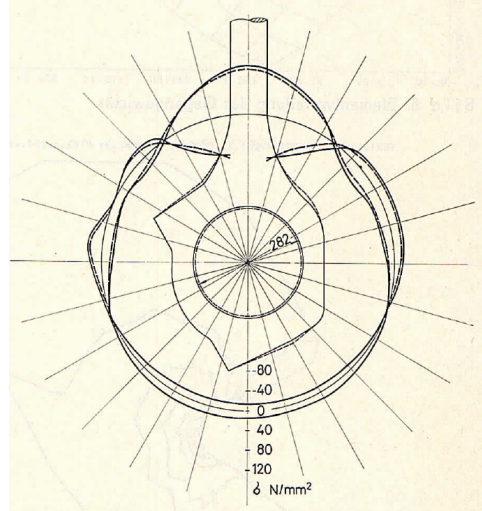

(c) Connecting Rod deformations

Figure 7. Pictures from the very first FEM paper, year 1976 [12]

\section{The nineties building the basics}

In the nineties, Wärtsilä engines Calculation and Simulation team started to use the Ideas and Abaqus combination in FEM work. The story behind the switch is quite interesting. Technology Director Daniel Paro had a large connections network including some from ABB Sweden, where they used the Ideas and Abaqus combination for FEM work. Daniel organized a meeting, where the ABB simulation team presented Ideas and Abaqus features to the Wärtsilä simulation team. After the meeting, Daniel asked for the opinion of Gösta, the head of the Calculation and Simulation team. He stated that they were satisfied with the current combination of Patran and Adina, to which Daniel simply stated - "No, Wärtsilä will change to Ideas and Abaqus," which was the end of discussion and Wärtsilä switched to them. [10]

In a way, talking about tools is irrelevant. The crankshaft is the most loaded, and thus most calculated engine component, sometimes even called the heart of the engine. It is also the only component for which we have dedicated calculations rules, a standard for classification [24]. In the nineties, crankshaft calculation methodology was developed and published in these theses [25-29].

Furthermore, the most calculated components are the cylinder head and cylinder liner. There are thermo-mechanical harsh loading conditions [30-33] present in these component 
Table 1. Wärtsilä Structural Analysis and Dynamics history milestones

\begin{tabular}{l|l|l} 
year & event & tokens \\
\hline 1970 & Pen and paper, slide rule & \\
1973 & 1973 first FEA in Wärtsilä, cylinder liner & \\
1980 & the first own computer for calculations 0.5 MIPS & \\
1990 & hydrodynamic bearing calculations with AVL software & \\
1991 & SGI Personal Iris introduction, Adina as FEM solver & \\
1994 & SGI Challenge and I-Deas come to town & \\
1996 & Benchmark between different non-linear solvers Abaqus wins, ver- & \\
1996 & Sion 5.5 is chosen as successor of Adina & \\
1997 & David Hibbitt visits Wärtsilä & 24 \\
1999 & Abaqus 5.7 Hernelind visits Wärtsilä annually \\
1999 & Abaqus introduction to the others sites in the group (Trieste, & 24 \\
2000 & Zwolle, Mulhouse, and Winterthur) & \\
2001 & Abaqus 6.1 with new Licensing system & 24 \\
2003 & David Hibbitt visits Vaasa & 28 \\
2003 & HyperWorks as pre-processor & 25 \\
2006 & Simulation cluster introduction, ABAQUS Inc. is now Simulia & 25 \\
2008 & Simlab introduced as pre-processor & 51 \\
2009 & WITAL the first big simulation method development project starts & 72 \\
2010 & & 85 \\
2011 & "Limited unlimited" licensing system & 200 \\
2015 & Purchased Abaqus licenses and Introduction of 3DX & $600)$ \\
2017 & Wärtsilä is involved in the RM50 seminar organization \\
2018 & University co-operation to the next level, Tero Frondelius start as & 600 \\
& part-time Professor, Fatigue at Oulu University & \\
& & \\
&
\end{tabular}

calculations. Cylinder head simulations have always utilized the full available computing power, and even until recently it seems that the accuracy of the models compared with the wall clock time of the simulation running times is not satisfactory. However, previous as well as current methodologies have provided word class products of their time, and engineers have kept pushing the limits by increasing both the efficiency and power output of the engines.

From very early on, Wärtsilä has recognized the need for engine dynamics simulations and the dynamic design of Gensets, a power packet of engine and generator combined with a common base frame. The common base frame was selected as the tunable component, which meant that its design depended on the combinations of engine and generator. The theses [34-42] present the methodology development.

In the early nineties MS-DOS-based in-house software for flexible mounting calculation was developed in collaboration with the Tampere University of Technology. It was based on the rigid body natural frequency calculation of a system where an engine or a generating set is standing on soft rubber mounts. This S.c. REMO software, combined with experimental modal analysis, which also started in the early nineties, was a powerful tool for designing engine installations. 
Adina calculated the natural frequencies of engines and generating sets. It is commercial FEM software and the results was compared with experimental modal analysis results. Many studies were done to find suitable modeling techniques, and to reasonably simplify models without sacrificing too much accuracy.

In the nineties, a major development took place in engine dynamics simulation, see details in [43-52]. The methodology of calculating only natural frequencies was finally considered to be insufficient, because of the increased excitation forces due to higher output with fewer emissions. Thus, a harmonic response calculation methodology was required and developed. This development started with studying engine dynamic excitation forces in detail and building computer software for their calculation. An important part of understanding the excitations, and the way affect the engine structure, is the visualization of the forces and internal moments. The need for quick calculation and visualization leads the DYNEX software development. Further development in the late nineties consisted of adding the export function of the dynamic forces to Finite Element software, enabling forced response simulation. It is possible to simulate the engine vibration response at a constant or varying speed. In the beginning, DYNEX made the export to Ideas "program" format, but when this format became obsolete, the export function was rewritten to support "Universal File Format," and the conversion to Abaqus input format was later added. DYNEX has played a major role in engine dynamics simulations for more than fifteen years, until the multi-body simulation tools' introduction to production usage.

Eventually, all loading in engines is fatigue loading by nature. Thus, fatigue calculation methodology needed to develop to guarantee human safety in the increasing competition of increasing the power outputs. These publications describe the development [53-57].

Gear train dynamics, namely camshaft gear train dynamics, have been under investigation since the nineties [58-60]. Naturally, in the four-stroke engine, the camshaft torsional vibrations are especially important to handle, in order to design a smoothly running engine. The peculiarity of the medium speed engines are the multiple fuel pumps, even with each cylinder having one pump. These are significant loading, for example, in full power the pumps excitations to the camshaft are three times higher than excitations from valve lifting.

This takes us nicely to the next topic, elastohydrodynamic bearing calculations. They also started very early on [61] in 1994. The engine is full of highly loaded slider bearings, and their reliability has been and still is one of the cornerstones of the engine development. Pistons [62] have slider bearings and other demanding loads.

This paper focuses on structural analysis and dynamics, however the right boundary and loading conditions are needed, and can often be provided by CFD simulations. These theses [63-69] present some of the early CFD simulations.

\section{Millennium with the wind of change}

Roger Rabb finalized his basic research of statistical fatigue methodology development at the end of the nineties. To take that into the operative calculations, a leap to next level was needed, and indeed performed. These publications give the details: [70-84].

Another, fatigue-related, phenomenon, namely fretting research need, was born. The start of the long-lasting method development is described in detail in these publications [85-99]. Fretting typically occurs when the design scales upward. Thus, manufacturers with physically large products are usually aware of the fretting phenomena. Due to this fact, the fretting research is not as mature as the fatigue research, and therefore it provides 


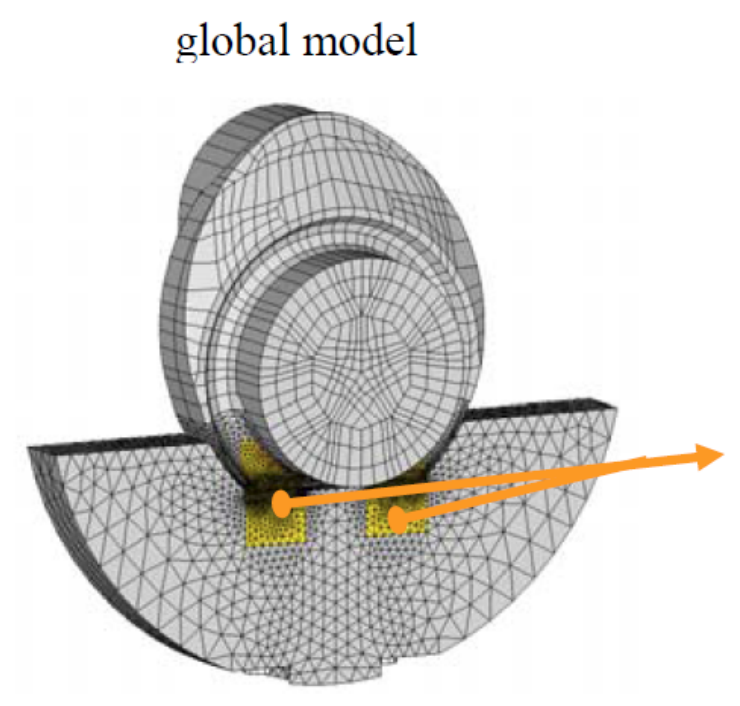

submodel

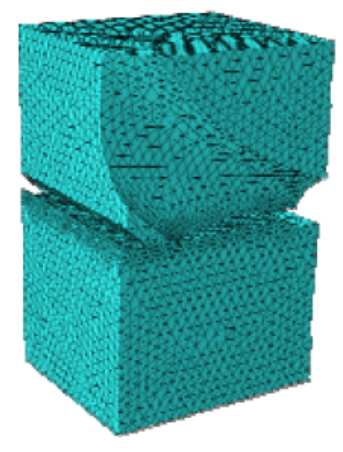

Figure 8. Finite element models for the fretting analysis [85]

a virgin ground for new development. See one example of the crankshaft counterweight fretting simulation model in Figure 8.

Something old was improved as well. Each decade attempted to improve the cylinder head calculation methodology. This time [100], the geometric model complexity had already reached the status where the full cylinder head assembly, together with the engine block, liner and all cylinder head equipment solve together. Of course, a lot of room for future improvements remains, and more of those are presented in the next section.

Continuing with the dynamics, camshaft dynamic calculation method needed to take into account the change in gear contacts, which changes the dynamics behavior and forced response of the camshaft. Theses [101-103] present the details.

References $[104,105]$ show a new attempt towards the multi-body system modeling of the crankshaft and connecting rod. However, the organization was not yet ready for this new methodology, thus more about the virtual engine modeling is presented in the next section. Slider bearing calculations are as important as always, and one thesis was made on the topic [106] in 2006. CFD [107-109] also continued its development.

In the year 2007, the world economics were overheated and especially in the marine sector it seemed that there would be an unlimited amount of business growth before it all collapsed in 2008. Nevertheless, a new employee recruitment program called Wärtilä Young Professional was established to bait skilled resources. [10] The idea of the recruitment training program was to give a speedy start for new employees to catch up with the challenges of competencies of different types of engine expertise. Fundamentally, the idea of the program was to hire experts from different fields and give them all an introduction to all different competence areas. The analysis area with the team of Structural Analysis and Dynamics was one of the themes. The program was somewhat successful and was later modified on into an internal training program called R\&D Professionals. In the Structural Analysis and Dynamics team, we have one from the original training program and four from the follow-up programs. All of those who have participated have given much credit to the training programs. They have felt that their employer has invested in them. 


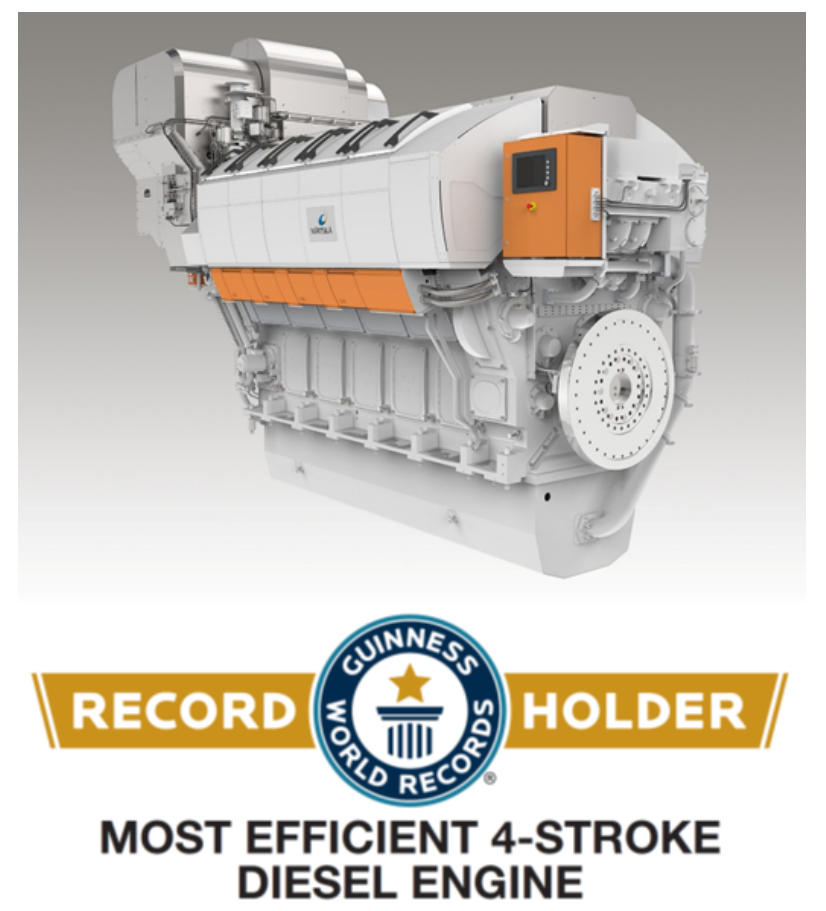

Figure 9. W31 2015 Most Efficient 4-stroke Diesel Engine [110]

\section{Leaping to the modern computing age from 2010 until now}

A good start of the new decade was the Wärtsilä virtual engine simulation methodology development, see Figure 10 for an example of the model complexity. Papers [111-129] present the details. The idea of the virtual engine was to have as realistic an engine dynamics model as possible. Ideally, the same model is used for engine acoustics, then all the engine covers and similar are included in the simulation model. The same virtual engine models are typically used for modern crankshaft [130-137] simulations, including elastohydrodynamics $[138,139]$ bearing models. In addition, in connecting rods calculations, a virtual engine modeling approach can be used [140,141].

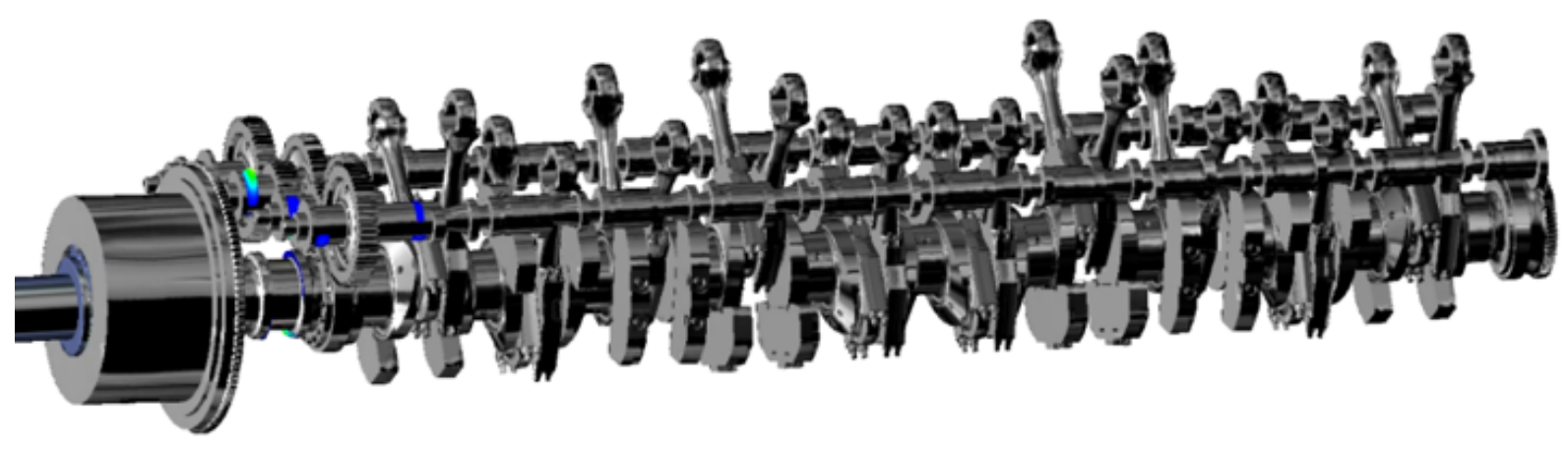

Figure 10. Virtual engine model of powertrain of medium speed diesel engine [128]

This decade was the time to get into the Simulation Process and Data Management (SPDM) [142-154]. Some fundamental basic research was needed and performed. Eventually, the implemented system, Wärtsilä Digital Design Platform [152], contained all 
the product detail requirements and combined them into the actual simulation processes, which provided the values to the requirements. It also included task management tools, giving both line and project managers a real-time view of the status of project resources and tasks.

The cylinder head simulation methodology finally took a giant leap into the modern days, see details in [155-162]. The state-of-the-art methodology of the whole cylinder head calculation process started from very detailed cylinder gas exchange modeling, continuing in the conjugate heat transfer [163] simulation model, which was run parallel to the gas exchange model to find the stable boundary conditions for the structural FEM calculations. The following FEA will take inputs from the conjugate heat transfer analysis, casting simulations and gas exchange analysis. The material model is microstructure as well as temperature dependent. After the FEA follows a combined low-high cycle fatigue analysis, see Figure 11 for example results. Those critical points where the desired lifetime is lower than expected are taken into detail crack propagation analysis. If the crack initiates, but does not propagate too far, it is called damage tolerant design and considered good enough.
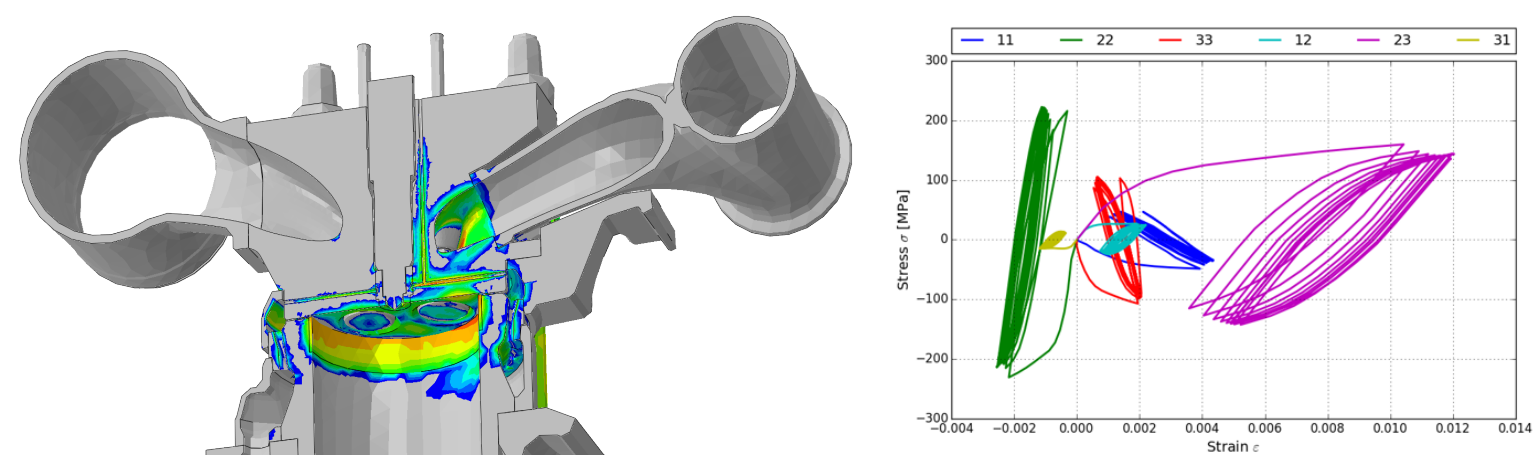

Figure 11. Results of modern cylinder head simulation methodology, fatigue lifetime and stress-strain history of one material point [160]

Next, it is just logical to continue with the fatigue methodology development review. The following references [160,164-185] give all the details. The major aspects to point out are micromechanics modeling and Bayesian statistics. Micromechanics modeling aims towards virtual fatigue testing, where the idea is to tune the micromechanics model to the exact interesting fatigue test points and then, when the micromechanics model can predict already measured test specimens, it will be used to interpolate and extrapolate the test matrix. This is true especially in the regions where the traditional fatigue test is either difficult or time consuming, namely testing the compress side of the Haigh-diagram and multi-axial fatigue loading.

What is more, fretting research has taken a huge leap as well; please see the details in the following references [186-216]. The most significant achievement in fretting method development has been the operational calculations development. It does not matter how advanced the simulation methodology is unless one will get it to the production usage, where one will see fretting-safe designs in products. Currently, the authors are satisfied with how fast the Wärtsilä Structural Analysis and Dynamics department has been able to implement newly developed research results into the products. However, fretting remains in a way the untamed beast, and it will guarantee a plenty of future challenges for researchers. 
The last paragraph is dedicated to loosely related research topics. Acoustics methodology went through some development $[217,218]$. Big data measurements analysis $[219,220]$ was something that needed to be tackled to get an understanding of the needed loading cases, so that they would represent real-world extreme loading conditions. All types of optimizations [221] are the cornerstone of the modern product development. Surprisingly, we have published an insufficient amount of information in the field. Some new studies on how to model brittle material were also performed [222], with the aim of human safety and reliability of our products. Finite element open source solver development [223-225] is something that was intentionally started to create a flexible and easy-to-use research platform. JuliaFEM is an attempt to create a common research platform for engineering mechanics numeric research in Finland. Currently, we are living an early stage, but academia has shown some interests. See also [226] for the start of the material modeling.

\section{Conclusion}

This paper attempted to open the structural analysis and dynamics method developments in the Wärtsilä engine division in the last five decades. As mentioned throughout the text, the authors consider Wärtsilä an excellent example of the industry, one that is dedicated to its product development so sternly that it is willing to do basic research to guarantee the needed competencies and skills in the company in order to make the most reliable products.

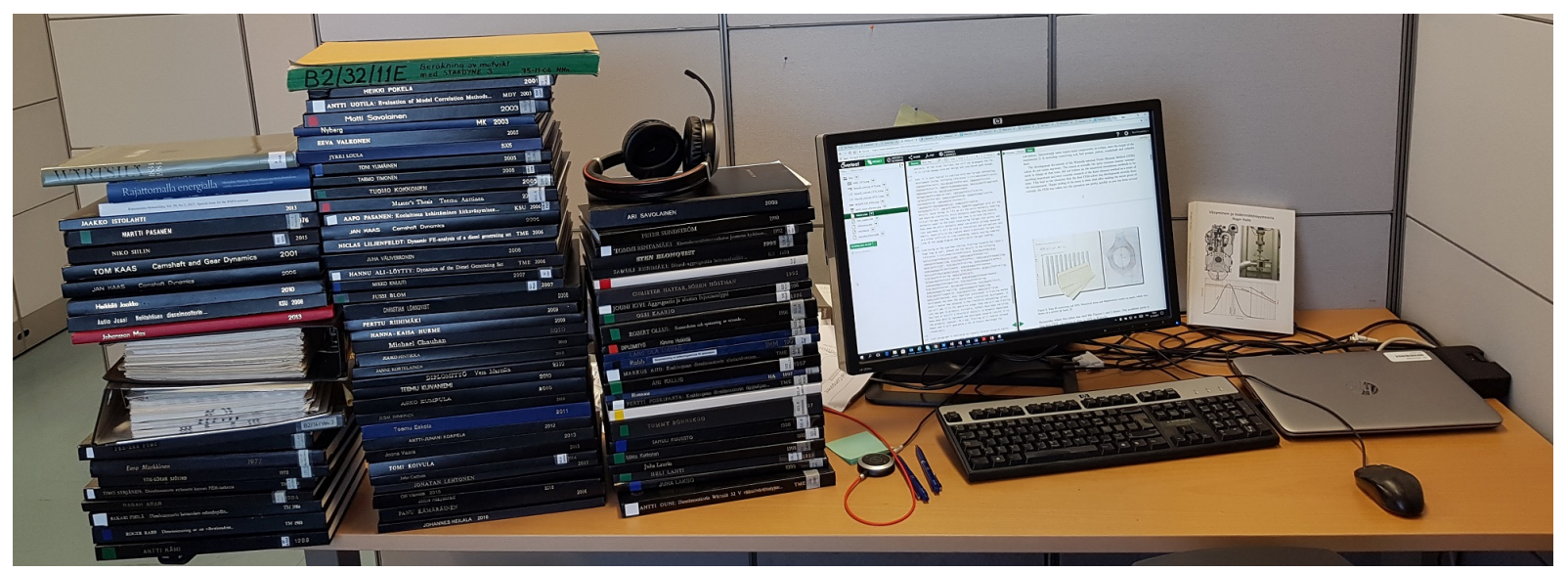

Figure 12. Researcher's desk when writing this paper

We went through the early days of Finite Element Method (FEM) developed on the borrowed computer, and described the chicken and egg race of more significant computing results leading to more complex models that demand more computing resources. We added stories to the internal software development as well as the real driver, field problems, examples. In the final section, we leaped to a whole new level of simulation methodologies.

We have mentioned a few times when we believe that Wärtsilä has been an early adopter of the technology, or even the fundamental developer of it. Eventually, all the hard work paid off, and the Guinness World Records of the most efficient 4-stroke diesel engine was received in 2015, see Figure 9.

Figure 12 shows a part of the overwhelming task of going through all the references. Although it took a considerable amount of effort, the authors believe it was worthy for gaining a better understanding of what we have done and where we should be heading. It 
also revealed the somewhat surprising fact that Wärtsilä has not published much about optimization development as such. Structural analysts have mentioned optimization in some articles as a side note, but we have indeed not published as much as we have used it internally.

\section{Acknowledgement}

The authors would like to acknowledge professor Reijo Kouhia, who gave us the idea for this paper. What happened was that Tienhaara gave the keynote speech Fifty years of structural mechanics and simulation in Wärtsilä at the 50-year anniversary seminar of Rakenteiden Mekaniikan Seura, on August 24th, 2017 in Vaasa, Finland [227]. After the presentation, Reijo presented a request from the audience: please publish a journal article on this topic in Rakenteiden Mekaniikka.

In addition, the Wärtsilä authors would like to acknowledge the financial research support from Business Finland (formerly Tekes) to the research projects WITAL, Frefa, Freda and Wimma that enables a lot of the work presented in this paper. Additionally, the authors would like to give recognition to two Tekes employees, Kari Penttinen and Matti Säynätjoki, who have participated in the steering group meetings of the research projects and given their valuable contributions there. The authors would like to acknowledge Gösta Liljenfeldt for multiple interviews and phone calls, as well as the arrangement of Harry Holmgren's interview.

\section{References}

[1] Gösta Liljenfeldt. Computers in diesel engine development. Wärtsilä Marine News, 2/1992, 1992.

[2] Kurt Hagelberg. Sinapinsiemen kylvetään. In Johan Stoor and Anneli Frantzén, editors, Rajattomalla Energialla: Muistelmia Wärtsilän Vaasan Tehtaan Moottorivalmistuksen Viideltä Ensimmäiseltä Vuosikymmeneltä, chapter 1, pages 3651. Työryhmä WV-minnen 2009, 2009. URL: https://www.finna.fi/Record/ jykdok.1133631?lng=fi.

[3] Pentti Rajamäki. Runkolaakerisatulan kuormitus ja muodonmuutokset. Wärtsilä internal report B2/22/10B, May 1973.

[4] Timo Syrjänen. Dieselmoottorin sylinterin kannen FEM-laskenta, 1983. Master's thesis from Tampere University of Technology. URL: https://tut.finna.fi/ Record/tutcat. 251469.

[5] Per Åke Furu. Undersökning av spänningar och deformationer i en vevstake, 1970. Master's thesis from Helsinki University of Technology.

[6] Gösta Liljenfeldt. En undersökning av tryckförlopp i bränslematarsystemet på medelvarviga dieselmotorer, 1972. Master's thesis from Tampere University of Technology. URL: https://tut.finna.fi/Record/tutcat. 2296.

[7] Martti Pasanen. Jäähdytysöljyn tilavuusvirran vaikutus keskinopean dieselmoottorin männän lämpötiloihin, 1976. Master's thesis from Helsinki University of Technology. 
[8] Eero Markkinen. Tutkimus keskinopean laivadieselmoottorin kampiakselin lujuuslaskentamenetelmistä, 1977. Master's thesis from Helsinki University of Technology.

[9] Olgierd Cecil Zienkiewicz and Robert Leroy Taylor. The finite element method, volume 3. McGraw-hill London, 1977.

[10] Gösta Liljenfeldt. personal communication, 2017.

[11] Harry Holmgren. personal communication, 2017.

[12] Matti Kleimola and Harry Holmgren. Verwendung der finite-element-methode bei der entwicklung von dieselmotoren. MTZ Motortechnische Zeitschrift, 37:231-234, 1976.

[13] Stig-Göran Sjölind. Beräkning av värmespänningar i en dieselmotors cylinderfoder enligt finita elementmetoden, 1978. Master's thesis from University of Oulu.

[14] Roger Rabb. personal communication, 2017.

[15] Sakari Pisilä. Dieselmoottorin keraamisen männänpään lujuus- ja luotettavuustarkastelu, 1986. Master's thesis from Tampere University of Technology. URL: https://tut.finna.fi/Record/tutcat. 249517.

[16] Rabah Arar. Analyse des structures du bati d'un moteur Wärtsilä 12 V22HF et du generateur strömberg HSPTL 12/754, 1984. Master's thesis from Ecole Superieure polytechnique.

[17] Roger Rabb. Dimensionering av ett vibrationsfritt fundament för ett die selelektriskt aggregat, 1988. Master's thesis from Tampere University of Technology. URL: https://tut.finna.fi/Record/tutcat.126781.

[18] Antti Kämi. Impedanssifunktioiden käyttö massiivisten koneenperustusten suunnittelussa, 1989. Master's thesis from Helsinki University of Technology.

[19] K. Saine, A. Veijalainen, and P. Häkkinen. Optimum design of resilient diesel engine installations using computer aided testing and finite element method. CIMAC, International Congress on Combustion Engines, 18th, Tianjin, CN, 1989-06-05 1989-06-08, 1989.

[20] I. Ahlqvist, C.E. Rösgren, and H. Holmgren. Using CAD in a diesel engine design office - can it produce something really new? CIMAC, International Congress on Combustion Engines, 16th, Oslo, NO, 1985-06-03 - 1985-06-07, 1985.

[21] D. Paro, G. Liljenfeldt, and T. Martikainen. Investigation of the influence of the stroke/bore ratio on the thermodynamical and mechanical behavior of high-powered diesel engines. CIMAC, International Congress on Combustion Engines, 17th, Warsaw, PL, 1987-06-08 - 1987-06-11, 1987.

[22] A. Silvonen and S. Pisilä. Reliability and its determination for medium speed diesel engine components. CIMAC, Proceedings of the 18th International Congress on Combustion Engines, Diesel Engines, Volume 1, Tianjin, CN, 5-8 Jun, 1989, 1989. 
[23] H.J. Köhner and M.D. Röhrle. Pistons for heavy fuel operation. CIMAC, International Congress on Combustion Engines, 15th, Paris, FR, 1983-06-30, 1983.

[24] UR IACS. M53. Calculation of Crankshafts for IC Engines, 2004.

[25] Peter Sundström. Specificering av torsionssvänningsrelaterade dieselmotorkomponenter, 1990. Master's thesis from University of Oulu.

[26] Tommi Rintamäki. Kierrosluvunsäätimen vaikutus joustavan kytkimen dynaamiseen kuormitukseen, 1992. Master's thesis from Tampere University of Technology. URL: https://tut.finna.fi/Record/tutcat.88732.

[27] Robert Ollus. Konstruktion och optimering av vevaxeln för en stor medel varvig dieselmotor, 1996. Master's thesis from Helsinki University of Technology.

[28] Mikko Kekkonen. Luokitusseurojen laskentamenetelmät kampiakselin käytettävyyden arvioinnissa, 1998. Master's thesis from Helsinki University of Technology.

[29] Antti Ouni. Dieselmoottorin Wärtsilä $32 \mathrm{~V}$ vääntövärähtelyjen vaimentaminen, 1999. Master's thesis from Tampere University of Technology. URL: https://tut. finna.fi/Record/tutcat.136605.

[30] Sten Blomqvist. Hållfashetsanalys av ett cylinderfoder för en medel varvig dieselmotor, 1993. Master's thesis from University of Oulu.

[31] Kimmo Heikkilä. Epästationaarisesta kuormituksesta aiheutuvat lämpöjännitykset keskinopean dieselmoottorin sylinterinkanteen, 1996. Master's thesis from Lappeenranta University of Technology. URL: https://wilma.finna.fi/lut/Record/ wilma. 57174.

[32] Juha Laurio. Keskinopean kaasumoottorin esikammion ja sylenterikannen välisen tiivistyksen simulointi, 1998. Master's thesis from Helsinki University of Technology.

[33] Juha Lakso. Test of a numerical method for defining the themperature distribution of a cylinder head, 1999. Master's thesis from University of Oulu.

[34] Samuli Riihimäki. Diesel-aggregaatin betonialustan värähtelyanalyysi, 1993. Master's thesis from Tampere University of Technology. URL: https://tut.finna. fi/Record/tutcat. 94967.

[35] Juhani Olavi Kujala. 4-tahtisen dieselmoottorin värahtelytasojen määrittämisessä saavutettavat edut kunnonvalvonnassa ja tuotekehityksessä, 1994. Bachelor's thesis from Vaasan Teknillinen Oppilaitos.

[36] Petri Aaltonen. Joustavasti asennetun moottorin alustarakenteiden värähtely, 1994. Master's thesis from Tampere University of Technology. URL: https: //tut . finna. fi/Record/tutcat. 248731.

[37] Olli Nuutila, Kari Saine, and Hannu Tienhaara. The effect of non-linarites of rubber elements on the behaviour of resilient mounting system. In Model Analysis Theory and Application Jan 27-29 1994 Honolulu Hawaii Proceedings, 1994. 
[38] Jouni Kivi. Aggregaatin ja alustan lujuusanalyysi, 1996. Master's thesis from Tampere University of Technology. URL: https://tut.finna.fi/Record/tutcat. 116736.

[39] Markus Aho. Keskinopean dieselmoottorin alustarakenteen fem-analyysi, 1997. Master's thesis from Tampere University of Technology. URL: https://tut. finna. fi/Record/tutcat. 251461.

[40] Kari Saine, Olli Nuutila, and Hannu Tienhaara. Optimisation of a concrete block for a diesel-aggregate. In The 5th International Congress on Sound and Vibration (ICSV5) 1997-12-15-1997-12-18, Adelaide, AUSTRALIA, 1997.

[41] Pertti Poskiparta. Keskinopean dieselmoottorin öljypohjan FEM-analyysi, 1997. Master's thesis from Tampere University of Technology. URL: https://tut. finna. fi/Record/tutcat.122432.

[42] Heli Lahti. Keskinopean dieselmoottorin lohkon jännitys- ja ominaistaajuusanalyysi, 1999. Master's thesis from Helsinki University of Technology.

[43] Hannu Tienhaara, Reinoud Fennema, and Juha Lakso. Harmonic response analysis of a medium speed diesel generating set. In $C D$ : ICSV 7, 7th International Congress on Sound and Vibration, volume 1. Kramer Technology Publishing, 2000.

[44] Antti Uotila. evaluation of model correlation methods in engine-generator assembly vibration analysis, 2003. Master's thesis from Tampere University of Technology.

[45] Hannu Tienhaara. Guideline to engine dynamics and vibration. 2004. URL: http://www.lme.ntua.gr:8080/academic-info-1/prospheromena-mathemata/ egkatastaseis-prooses/files/guidelines_dynamics_vibration.pdf.

[46] Niclas Liljenfeldt. Dynamic fe-analysis of a diesel generating set : Master of science thesis, 2006. Master's thesis from Tampere University of Technology. URL: https: //tut.finna.fi/Record/tutcat.184074.

[47] Hannu Ali-Löytty. Dynamics of the diesel generating set, 2007. Master's thesis from Tampere University of Technology. URL: https://tut.finna.fi/Record/ tutcat. 184072.

[48] Hannu Tienhaara and Heikki Mikonaho. Engine dynamics and vibration control. CIMAC, Proceedings of the 25th CIMAC World Congress on Combustion Engine, Wien, AT, May 21-24, 2007, 2007.

[49] Jussi Blom. Dieselgeneraattorin välilaipan kehittäminen, 2007. Master's thesis from Helsinki University of Technology.

[50] A. Trondle, B. Flury, C. Mathey, H. Tienhaara, V. Hilakari, and H. Mikonaho. Vibration suppressor, July 5 2007. US Patent App. 11/607,981. URL: https: //www.google.fi/patents/US20070151242.

[51] Hannu Tienhaara and Heikki Mikonaho. Engine dynamics and vibration control. Wartsilla Technical Journal, pages 56-61, 2008. 
[52] Frederik Östman. Cylinder Balancing of Medium-Speed Internal Combustion Engines: Academic Dissertation. PhD thesis, 2009.

[53] Aulis Silvonen and Sakari Pisila. Reliability and its determination for medium speed diesel engine components. Technical Research Centre of Finland, Fatigue Design 1990 p 303-322(SEE N 91-15575 07-39), 1990.

[54] Roger Rabb. Fatigue failure of a connecting rod. Engineering Failure Analysis, 3(1):13 - 28, 1996. URL: https://doi.org/10.1016/1350-6307(95)00034-8.

[55] Leif Rabb. Dimensionering av befästningsskruvar för generatorer, 1997. Bachelor's thesis from Svenska Yrkenhögskolan.

[56] B Roger Rabb. Fatique Testing and Its Statistical Evaluation Into Design Rules. Tampere University of Technology, 1999.

[57] Roger Rabb. Fatigue life evaluation of grey cast iron machine components under variable amplitude loading. European Structural Integrity Society, 23:51-63, 1999.

[58] Jouni Lampinen. Dieselmoottorin nokka-akseleiden mitoitusmenetelmän kehittäminen, 1997. Master's thesis from University of Vaasa. URL: https://tritonia. finna.fi/Record/tria.75583.

[59] Tommy Rönnskog. En nockaxel växels lastutbredningsfaktor, 1997. Master's thesis from Helsinki University of Technology.

[60] Samuli Kuusisto. Transient nonlinear dynamics of camshafts, 1998. Master's thesis from University of Oulu. URL: https://oula.finna.fi/Record/oula. 563810.

[61] Pasi Halla-aho. Pieniliikkeisen laakerin elastohydrodynaaminen laskenta, 1994. Master's thesis from Tampere University of Technology. URL: https://tut.finna.fi/ Record/tutcat. 107010.

[62] A. Silvonen, T. Ahlroth, and P. Halla-aho. Piston unit for an internal combustion engine, March 10 1998. US Patent 5,724,933. URL: https://www.google.fi/ patents/US5724933.

[63] Christer Hattar and Sören Höstman. Grundkonstruktion av en medel varvig dieselmotor, 1995. Master's thesis from Helsinki University of Technology.

[64] Ossi Kaario. Keskinopean dieselmoottorin työkierron laskenta fire-ohjelmalla, 1996. Master's thesis from Helsinki University of Technology.

[65] Lars Ola Liavåg. Development of a plume combustion model for a thermodynamic engine model, 1996. Master's thesis from Universitet i Trondheim.

[66] Pertti Taskinen, Reijo Karvinen, Gosta Liljenfeldt, and Heikki J Salminen. Simulation of heavy fuel spray and combustion in a medium speed diesel engine. Technical report, SAE Technical Paper, 1996. URL: https://doi.org/10.4271/962053.

[67] Ari Kallio. virtauslaskentaohjelmiston käyttö kaksitahtidieselmoottorin huuhtelun laskennassa, 1997. Master's thesis from Helsinki University of Technology. 
[68] Pertti Taskinen, Reijo Karvinen, Gösta Liljenfeldt, and Heikki J Salminen. Combustion and nox emission simulation of a large medium speed diesel engine. Technical report, SAE Technical Paper, 1997. URL: https://doi.org/10.4271/972865.

[69] Pertti Taskinen, Philipp Von Hollen, Reijo Karvinen, Gösta Liljenfeldt, and Heikki J Salminen. Simulation of combustion, soot and nox-emissions in a large medium speed diesel engine. Technical report, SAE Technical Paper, 1998. URL: https: //doi.org/10.4271/981449.

[70] Gary Marquis, Roger Rabb, and Laura Siivonen. Endurance limit design of spheroidal graphite cast iron components based on natural defects. In Fatigue Crack Growth Thresholds, Endurance Limits, and Design. ASTM International, 2000.

[71] R. B. Rabb. Interpretation and evaluation of the statistical size effect. CIMAC, Proceedings of the 23rd World Congress on Combustion Engine Technology for Ship Propulsion, Power Generation, Rail Traction, Vol. 4, Hamburg, DE, May 7-10, 2001, 2001.

[72] Mikael Nyberg. Low cycle fatigue behavior of a hydraulic screw tightening tool, 2003. Bachelor's thesis from Svenska Yrkenhögskolan.

[73] Roger B Rabb. Staircase testing-confidence and reliability. WIT Transactions on Engineering Sciences, 40, 2003.

[74] Gary B Marquis, Roger B Rabb, and Päivi Karjalainen-Roikonen. High cycle variable amplitude fatigue of a nodular cast iron. Journal of ASTM International, $1(8): 1-17,2004$.

[75] R B Rabb. Influence of occasional underloads on fatigue. In European Congress on Computational Methods in Applied Science and Engineering, ECCOMAS, pages 24-28, 2004.

[76] Eeva Valkonen. Algoritmi pienimmän pisteet sisältävän hyperpallon laskemiseksi moniaksiaaliseen dang vanin väsymiskriteeriin, 2005. Master's thesis from Tampere University of Technology. URL: https://tut.finna.fi/Record/tutcat.179843.

[77] Tarmo Timonen. Calculation of the effective stress area in an abaqus environment, 2005. Master's thesis from University of Oulu. URL: https://oula.finna.fi/ Record/oula.875592.

[78] Magnus Lassus and Roger Rabb. Multiaxial fatigue analysis in abaqus environment. part 2: Implementation. In ABAQUS Users Conference Proceedings May, pages 277-290, 2005.

[79] Roger Rabb and Magnus Lassus. Modern multiaxial fatigue analysis in abaqus environment. part 1: Theory. In ABAQUS Users Conference Proceedings May, pages 18-20, 2005.

[80] Juha Väliverronen. Multiaxial fatigue in connecting rod bolts, 2006. Master's thesis from University of Oulu. URL: https://oula.finna.fi/Record/oula. 926673. 
[81] C Lönnqvist, J Kaas, and R Rabb. Comprehensive multiaxial fatigue analysis with abaqus. In ABAQUS Users Conference Proceedings, pages 412 430, 2007. URL: https://www.3ds.com/fileadmin/PRODUCTS/SIMULIA/PDF/ scc-papers/Comprehensive-Multiaxial-Fatigue-2007.pdf.

[82] C Lönnqvist. Consistent multiaxial fatigue analysis, 2008. Master's thesis from Helsinki University of Technology.

[83] Hanna-Kaisa Hurme. Teräksen tilastollinen rakenneanalyysi, 2009. Master's thesis from Tampere University of Technology. URL: https://tut.finna.fi/Record/ tutcat.193468.

[84] R. Rabb, J. Solin, and C. Lönnqvist. Fatigue of screws including the influence of repeated tightening and untightening. In Second International Conference on Material and Component Performance under Variable Amplitude Loading. March 23-26, 2009, Darmstadt, Germany, volume 2, 2009. URL: http: //www.dvm-berlin.de/index.php?id=447.

[85] A Mäntylä and C Lönnqvist. Fretting simulation for crackshaft-counterweight contact. In SIMULIA Customer Conference, 2009. URL: http://www.simulia.com/ download/pdf2009/Mantyla_SCC2009.pdf.

[86] Tuomo Kokkonen. Kitkaväsymisen testauslaitteen kehittäminen, 2005. Master's thesis from Helsinki University of Technology.

[87] Aapo Pasanen. Koelaitteen kehittäminen kitkaväsymisen ja värähtelykulumisen tutkimiseen, 2006. Master's thesis from Tampere University of Technology. URL: https://tut.finna.fi/Record/tutcat.182269.

[88] A. Lehtovaara and R. Rabb. A numerical model for the calculation of fretting fatigue crack initiation for a smooth spherical contact. Tribologia, 25(1):23-30, 2006.

[89] Roger Rabb, Pekka Hautala, and Arto Lehtovaara. Fretting fatigue in diesel engineering. CIMAC, Proceedings of the 25th CIMAC World Congress on Combustion Engine, Wien, AT, May 21-24, 2007, 2007.

[90] R Rabb, P Hautala, and A Lehtovaara. Fretting fatigue in medium speed diesel engines. In Proc. 5th International Symposium on Fretting Fatigue (ISFF5), pages 24-26, 2007.

[91] R. Rabb, P. Hautala, and A. Lehtovaara. Fretting fatigue in diesel engineering, page 16 p. 2007.

[92] Simo Järvisalo. Kitkaväsymisen mittaus ja analysointi pallo-taso-kosketuksessa, 2007. Master's thesis from Tampere University of Technology. URL: https://tut. finna.fi/Record/tutcat.186329.

[93] Arto Lehtovaara and Roger Rabb. A numerical model for the evaluation of fretting fatigue crack initiation in rough point contact. Wear, 264(9):750-756, 2008.

[94] Perttu Riihimäki. Kitkaväsymisen kokeellinen tarkastelu, 2009. Master's thesis from Tampere University of Technology. URL: https://tut.finna.fi/Record/ tutcat. 193182. 
[95] Aapo Pasanen, Arto Lehtovaara, Roger Rabb, and Perttu Riihimäki. Friction behavior of quenched and tempered steel in partial and gross slip conditions in fretting point contact. Wear, 267(12):2200-2207, 2009.

[96] A Pasanen, A Lehtovaara, R Rabb, and P Riihimäki. On the fretting fatigue behavior of quenched and tempered steel in smooth point contact. Tribologia, Finnish Journal of Tribology, 2009.

[97] A Pasanen, S Järvisalo, A Lehtovaara, and R Rabb. Development of a test device for the evaluation of fretting in point contact. Lubrication Science, 21(2):41-52, 2009 .

[98] Jussi Immonen. Kitkaväsymisen mallinnus aaltopintaisessa puristusliitoksessa, 2009. Master's thesis from Tampere University of Technology. URL: https://tut.finna. fi/Record/tutcat.196315.

[99] Antti Mäntylä. Fretting simulation for crankshaft-counterweight contact, 2009. Master's thesis from University of Oulu. URL: https://oula.finna.fi/Record/ oula. 1052266.

[100] Ari Savolainen. Dieselmoottorin sylinterinkannen fem-analyysi, 2000. Master's thesis from Tampere University of Technology. URL: https://tut.finna.fi/Record/ tutcat. 144579.

[101] Tom Kaas. Camshaft and gear dynamics, 2001. Master's thesis from Umeå University.

[102] Toni Ylimäinen. Polttomoottorin nokka-akselihammaspyörästön melu, 2005. Master's thesis from University of Oulu. URL: https://oula.finna.fi/Record/oula. 887597.

[103] Jan Kaas. Camshaft dynamics, 2006. Master's thesis from Umeå University.

[104] Matti Savolainen. Analysis of crankshaft using multibody dynamics, 2003. Master's thesis from Tampere University of Technology. URL: http://www.doria.fi/ handle/10024/35171.

[105] Jyrki Loula. Nivellenkkien elementtimenetelmäanalyysin kehittäminen, 2005. Licenciate's thesis from Tampere University of Technology. URL: https://tut.finna. fi/Record/tutcat. 176336.

[106] Jussi Autio. Nelitahtisen dieselmoottorin tehon noston vaikutus kampilaakeriin, 2006. Master's thesis from Tampere University of Technology. URL: https://tut. finna.fi/Record/tutcat.181800.

[107] Heikki Pokela. Isojen pyörteiden menetelmän soveltuvuus moottorilaskentaan, 2001. Master's thesis from Helsinki University of Technology.

[108] Teemu Anttinen. Numerical modelling of combustion and emission formation in a diesel engine with differential fuel injection characteristics, 2005. Master's thesis from Lappeenranta University of Technology. URL: https://wilma.finna.fi/ lut/Record/wilma.67916. 
[109] Mikko Knuuti. Simulation of hydraulic circuit for variable inlet valve, 2007. Master's thesis from University of Oulu. URL: https://oula.finna.fi/Record/oula. 988261.

[110] Ulf Åstrand. The wärtsilä 31-the world's most efficient 4-stroke engine. Marine Engineering, 51(2):203-207, 2016.

[111] H. Mikonaho. Vibration damper, a method of producing a vibration damper and a dampening arrangement for dampening the vibrations of an engine, March 232010. US Patent 7,681,701. URL: https://www.google.fi/patents/US7681701.

[112] Johannes Hyrynen, Matias Aura, and Tero Frondelius. Virtual model of a large diesel engine. In Proceedings of the 18th International Congress on Sound and Vibration, pages 10-14, 2011.

[113] Antti Mäntylä and Teemu Kuivaniemi. Automatic pre-processing for engine multibody simulations. Altair Users Meeting, Gothenburg, Sweden, 2011.

[114] Tero Frondelius, Stanislav Marusic, Thomas Resch, and Matias Aura. High frequency analysis of a generator set using flexible multi-body dynamic approach. presentation in AVL User Meeting, 2011.

[115] Antti Korpela. Thermal elasticity in flexible multibody simulation, 2012. Master's thesis from University of Oulu. URL: https://oula.finna.fi/Record/oula. 1181111.

[116] H. Mikonaho. Dampening element of a vibration damper and a vibration damper, January 10 2012. US Patent 8,091,695. URL: https://www.google.fi/patents/ US8091695.

[117] F. Brighi, O. Contento, and M. Cattarinussi. Oil sump and oil sump arrangement, October 9 2014. WO Patent App. PCT/FI2014/050,183. URL: https://www. google.fi/patents/W02014162047A1?cl=en.

[118] Mats Östman, Reijo Leikas, Antti Ouni, and Niklas Wägar. Electricity network balancing for renewable energy integration. URL: https://www.wartsila.com/ docs/default-source/smartpowergeneration/content-center/articles/ electricity_network_balancing_for_renewable_energy_integration.pdf.

[119] Tero Frondelius. Experiences with optistruct in virtual engine analysis. presentation in 2nd Altair Powertrain Seminar, 2015. URL: http://www.altairatc.com/ EventPage . aspx?event_id=54\&name=Agenda.

[120] T. Frondelius. Base frame for supporting piston engine and generator, September 11 2015. WO Patent App. PCT/FI2015/050,125. URL: https://www.google.com/ patents/W02015132463A1?cl=en.

[121] Heikki Mikonaho, Hannu Tienhaara, Peter Andersson, Paul Klinge, Petteri Kokkonen, and Hannu Sainio. Mass damper, March 3 2015. US Patent 8,967,348. 
[122] Tero Frondelius, Juho Könnö, Thomas Resch, and Maria Jose SantosDescalzo. Genset simulation with online load generation and grid interaction. presentation in AVL International Simulation Conference, 2017. URL: https://www.avl.com/documents/10138/5176924/Structure+Dynamics . pdf/6ed7e660-8e73-474a-91c1-015e1581e98c.

[123] Juho Könnö, Tero Frondelius, Thomas Resch, and Maria Jose Santos-Descalzo. Simulation based grid compliance. In CIMAC Congress Helsinki, 2016.

[124] M. Almerigogna, U. Hauser, A. Pettirosso, and C. Pestelli. An arrangement for damping vibration attachable to a turbocharged internal combustion engine and a turbocharger unit for an internal combustion piston engine provided with an arrangement for damping vibration, November 23 2016. EP Patent App. EP20,140,703,105. URL: https://www.google.fi/patents/EP3094827A1?cl=en.

[125] T. Frondelius and J. Könnö. Base frame for supporting and lifting an internal combustion piston engine, March 24 2016. WO Patent App. PCT/FI2015/050,622. URL: https://www.google.com/patents/W02016042212A1?cl=en.

[126] Don Chool Lee, Hyojung Kim, and Ronald Barro. Structural analysis of large diesel generator in resilient and rigid support mounting based on vibration measurement. CIMAC, CIMAC World Congress on Combustion Engine, 28th, Helsinki, FI, 201606-06 - 2016-06-10, 2016.

[127] Antti Korpela, Marko Jokinen, Teemu Kuivaniemi, and Tero Frondelius. W4L20 VEBIC genset dynamics — baseframe design. Rakenteiden Mekaniikka, 50(3):292295, 2017. URL: https://doi.org/10.23998/rm.64943.

[128] Teemu Kuivaniemi, Antti Mäntylä, Ilkka Väisänen, Antti Korpela, and Tero Frondelius. Dynamic gear wheel simulations using multi body dynamics. Rakenteiden Mekaniikka, 50(3):287-291, 2017. URL: https://doi.org/10.23998/rm.64944.

[129] Diana Burdiel, Carlo Pestelli, Moreno Almerigogna, Alan Pettirosso, Heikki Mikonaho, Teemu Kuivaniemi, and Tero Frondelius. Matching simulated and measured eigen frequencies of medium speed diesel engine. Rakenteiden Mekaniikka, 50(3):206-210, 2017. URL: https://doi.org/10.23998/rm.65117.

[130] Matti Savolainen, Hannu Tienhaara, Thomas Resch, and Branimir Smiljanic. Comparison of crankshaft calculation methods with reference to classification societies' requirements. CIMAC, 26th CIMAC World Congress on Combustion Engine, Bergen, NO, Jun 14-17, 2010, 2010.

[131] Aulis Silvonen, Pasi Halla-aho, and Toni Hakkarainen. Modern ultrasonic quality evaluation of large crankshafts. CIMAC, 26th CIMAC World Congress on Combustion Engine, Bergen, NO, Jun 14-17, 2010, 2010.

[132] Fredrik Östman and Hannu T Toivonen. Torsional system parameter identification of internal combustion engines under normal operation. Mechanical Systems and Signal Processing, 25(4):1146-1158, 2011. 
[133] Fredrik Ostman and Hannu T Toivonen. Adaptive cylinder balancing of internal combustion engines. IEEE Transactions on Control Systems Technology, 19(4):782791, 2011.

[134] John Carlson. Cylinder balancing based on torsional vibration : measurement algorithm implementation on a medium-speed engine automation platform, 2014. Master's thesis from University of Vaasa. URL: http://www.tritonia.fi/?d=244\&g= abstract\&abs $=6105$.

[135] T. Frondelius, K. Gustafsson, R. Gustafsson, and P. Halla-Aho. An on-site residual stress creation tool for and method of treating a crankshaft bearing surface and/or crankshaft bearing fillet, October 15 2015. WO Patent App. PCT/FI2015/050,244. URL: https: //www.google.com/patents/W02015155414A1?cl=en.

[136] Tero Frondelius, Pasi Halla-aho, and Antti Mäntylä. Crankshaft development with virtual engine modelling. In CIMAC Congress Helsinki, 2016.

[137] Ilkka Väisänen, Antti Mäntylä, Antti Korpela, Teemu Kuivaniemi, and Tero Frondelius. Medium speed engine crankshaft analysis. Rakenteiden Mekaniikka, 50(3):341-344, 2017. URL: https://doi.org/10.23998/rm.64916.

[138] Jaakko Valteri Heikkilä. Systematic inspection of hydrodynamic sliding bearings, 2010. Bachelor's thesis from Vaasan Ammattikorkeakoulu.

[139] Liang Bai, Teemu Kuivaniemi, Pasi Halla-aho, and Tero Frondelius. Elasto hydro dynamic simulation of the slider bearing. Rakenteiden Mekaniikka, 50(3):283-286, 2017. URL: https://doi.org/10.23998/rm.64922.

[140] Jaakko Istolahti. Mäntä-kiertokankiliitoksen kehittäminen korkeille sylinteripaineille, 2013. Master's thesis from Tampere University of Technology. URL: https://tut.finna.fi/Record/tutcat. 233780.

[141] Jussi Göös, Anton Leppänen, Antti Mäntylä, and Tero Frondelius. Large bore connecting rod simulations. Rakenteiden Mekaniikka, 50(3):275-278, 2017. URL: https://doi.org/10.23998/rm.64658.

[142] Vesa Marttila. Dieselmoottorin esisuunnittelun kehittäminen simuloimalla, 2010. Master's thesis from Lappeenranta University of Technology. URL: https : / wilma. finna.fi/lut/Record/wilma.151418.

[143] T. Frondelius, H. Tienhaara, and M. Aura. Moottorin simuloinnilla kohti tulevaisuuden haasteita. 24(1):25-26, 2010. Promaint Kunnossapidon media 1/2010.

[144] Teemu Eskola. Technology know-how capture, 2011. Master's thesis from University of Vaasa. URL: http://www.tritonia.fi/?d=244\&g=abstract\&abs=4239.

[145] Max Johansson. Benchmarking of engine parameters, 2013. Bachelor's thesis from Yrkenhögskolan Novia.

[146] Jaana Tamminen, Juha-Matti Myllykoski, Hannu Tienhaara, Mikael Österroos, Jussi Autio, and Johan Grankull. Front-loaded R\&D process for high quality development case Wärtsilä 31. 28th CIMAC World Congress on Combustion Engine, Helsinki, FI, Jun 6-10, 2016, 2016. 
[147] Jonne Haapakoski. Medium-speed four-stroke diesel engine cylinder pressure effect on component dimensioning, 2016. Master's thesis from University of Oulu. URL: http://urn.fi/URN:NBN:fi:oulu-201612023172.

[148] Johannes Heilala. Concept calculation tool for dynamics of generator set common base frame, 2016. Master's thesis from University of Oulu. URL: http://urn.fi/ URN : NBN : fi : oulu-201612013128.

[149] Juho Könnö, Hannu Tienhaara, and Tero Frondelius. SPDM as foundation for design digitalization. In NAFEMS World Congress 2017. Nafems, 2017.

[150] Johannes Heilala, Teemu Kuivaniemi, Juho Könnö, and Tero Frondelius. Concept calculation tool for dynamics of generator set common baseframe. Rakenteiden Mekaniikka, 50(3):353-356, 2017. URL: https://doi.org/10.23998/rm.64925.

[151] Massimo Cattarinussi, Anton Leppänen, Juho Könnö, and Tero Frondelius. Cylinder head design of experiment by using the Wärtsilä digital design platform. Rakenteiden Mekaniikka, 50(3):330-332, 2017. URL: https://doi.org/10.23998/rm. 64923.

[152] Juho Könnö, Hannu Tienhaara, and Tero Frondelius. Wärtsilä digital design platform. Rakenteiden Mekaniikka, 50(3):234-238, 2017. URL: https://doi.org/10. $23998 / \mathrm{rm} .64621$.

[153] Juho Könnö. Simulation based grid compliance. in detail Wärtsilä Technical Journal, 2017. URL: https://www.wartsila.com/twentyfour7/in-detail/ simulation-based-grid-compliance.

[154] Hannu Tienhaara, Tero Frondelius, and Juho Könnö. Requirement and task management as a part of wartsila digital design platform. In CAASE18 The Conference on Advancing Analysis 85 Simulation in Engineering. Nafems.

[155] Asko Kumpula. Fem analysis of a cylinder head, 2010. Master's thesis from University of Oulu. URL: https://oula.finna.fi/Record/oula.1090484.

[156] Katri Mäkinen. 3d-ja fem-mallinnus, 2011. Bachelor's thesis from Vaasan Ammattikorkeakoulu. URL: http://urn.fi/URN:NBN : fi : amk-201105198728.

[157] F. Brighi, D. Lollis, V. Lattanzio, and M. Cattarinussi. Piston engine and cylinder liner, April 22 2015. EP Patent App. EP20,130,732,206. URL: https://www. google.fi/patents/EP2861856A1?cl=en.

[158] J. Könnö. A method of and a tool for peening a surface of a bore, December 172015. WO Patent App. PCT/FI2015/050,334. URL: https://www.google.fi/patents/ WO2015189460A1?cl=en.

[159] T. Frondelius and J. Könnö. An autofrettage apparatus for and a method of increasing a fatigue strength of a prechamber element, June 232016 . WO Patent App. PCT/FI2015/050,793. URL: https://www.google.com/patents/ W02016097467A1?cl=en. 
[160] Anton Leppänen, Asko Kumpula, Joona Vaara, Massimo Cattarinussi, Juho Könnö, and Tero Frondelius. Thermomechanical fatigue analysis of cylinder head. Rakenteiden Mekaniikka, 50(3):182-185, 2017. URL: https://doi.org/10.23998/rm. 64743.

[161] T. Frondelius and J. Könnö. Method of producing a cylinder head for an internal combustion piston engine, a cylinder head blank and a cylinder head of an internal combustion piston engine, June 23 2016. WO Patent App. PCT/FI2015/050,829. URL: https://google.com/patents/W02016097469A1?cl=fi.

[162] Antti-Jussi Vuotikka, Mikael Nyberg, Heikki Karhinen, and Tero Frondelius. Contact sealing simulation of high pressured diesel injector. Rakenteiden Mekaniikka, 50(3):313-317, 2017. URL: https ://doi.org/10.23998/rm.65060.

[163] Niko Siilin. Conjugate heat transfer study of an engine block, 2015. Master's thesis from Aalto University. URL: http://www.urn.fi/URN:NBN:fi: aalto-201512165766.

[164] Roger Rabb, Christian Lönnqvist, and Jan Kaas. Multiaxial fatigue criteria applied to medium speed diesel engines. In ICMFF9, 2010.

[165] Michael Chauhan. Elastic-plastic fatigue assessment of notched components, 2010. Master's thesis from Aalto University.

[166] Teemu Kuivaniemi. Fatigue analysis of a powder metallurgical injection component, 2010. Master's thesis from University of Oulu. URL: https://oula.finna.fi/ Record/oula.1081989.

[167] Anton Leppänen. Case hardening simulation with finite-element method, 2012. Master's thesis from University of Oulu. URL: https://oula.finna.fi/Record/ oula.1172090.

[168] M Chauhan, J Solin, J Alhainen, T Manninen, and C Lönnqvist. Cyclic behaviour and fatigue of stainless steels. La Metallurgia Italiana, (9), 2013.

[169] Roger Rabb. Todennäöisyysteoriaan pohjautuva väsymisanalyysi. Rakenteiden Mekaniikka, 45(3):162-187, 2012. URL: http://rmseura.tkk.fi/rmlehti/2012/ nro3/RakMek_45_3_2012_6.pdf.

[170] Roger Rabb. Todennäköisyysteoriaan pohjautuva väsymisanalyysi. ISBN: 978-952286-210-5. Books on demand, 2013.

[171] Matti Savolainen, Roger Rabb, Anton Leppaenen, Aulis Silvonen, Sylvia Leever, and Wolfgang Lluft. An approach for dimensioning case hardened components through utilisation of sophisticated fatigue analysis with the finite element method. 27th CIMAC World Congress on Combustion Engine, Shanghai, CN, May 13-16, 2013, 2013.

[172] Lasse Makkonen, Roger Rabb, and Maria Tikanmäki. Size effect in fatigue based on the extreme value distribution of defects. Materials Science and Engineering: A, 594:68-71, 2014. 
[173] Tom Gustafsson. Extended finite element method for computing stress intensity factors, 2014. Master's thesis from Aalto University. URL: http://www.urn.fi/ URN : NBN : fi : aalto-201507013701.

[174] Sami Holopainen, Reijo Kouhia, Juho Konno, and Timo Saksala. Computational modelling of high-cycle fatigue using a continuum based model. In Proceedings of the NSCM28: 28th Nordic Seminar on Computational Mechanics, pages 71-74. in Proceedings of the NSCM28, 2015. URL: https://tutcris.tut.fi/portal/ files/4602817/Holopainen_etal_NSCM28.pdf.

[175] Jonatan Lehtonen. Collocation method for solving stochastic elasticity problems with an uncertain domain, 2015. Master's thesis from Aalto University. URL: http://www . urn.fi/URN:NBN : fi : aalto-201503062021.

[176] Olli Väinölä. Fatigue analysis using micromechanics, 2015. Master's thesis from University of Oulu. URL: http://urn.fi/URN : NBN : fi : oulu-201601141014.

[177] Panu Kämäräinen. High-cycle fatigue testing of fillet weld root side using mock-up specimens, 2016. Master's thesis from Tampere University of Technology. URL: https://tut.finna.fi/Record/tutcat. 255785.

[178] Juho Könnö, Tero Frondelius, Antti Mäntylä, and Joona Vaara. Application of micromechanics to component design. Chalmers University of Technology, 2016.

[179] Jussi Korhonen, Juha Kuoppala, Miikka Väntänen, Joona Vaara, Mikko Turunen, Panu Kämäräinen, Jarkko Laine, Aulis Silvonen, and Tero Frondelius. Qt-steel very high cycle fatigue testing with ultrasonic. Rakenteiden Mekaniikka, 50(3):304-308, 2017. URL: https://doi.org/10.23998/rm.65059.

[180] Miikka Väntänen, Joona Vaara, Jukka Aho, Jukka Kemppainen, and Tero Frondelius. Bayesian sequential experimental design for fatigue tests. Rakenteiden Mekaniikka, 50(3):201-205, 2017. URL: https://doi.org/10.23998/rm.64924.

[181] Asko Kumpula, Joona Vaara, Anton Leppänen, and Tero Frondelius. Nodular cast iron ONERA fatigue model fitting. Rakenteiden Mekaniikka, 50(3):179-181, 2017. URL: https://doi.org/10.23998/rm.64740.

[182] Jussi Korhonen, Antti Mäntylä, Juho Könnö, and Tero Frondelius. Full scale fatigue testing of crankshaft. Rakenteiden Mekaniikka, 50(3):166-170, 2017. URL: https: //doi.org/10.23998/rm.65116.

[183] Joona Vaara, Antti Mäntylä, and Tero Frondelius. Brief review on high-cycle fatigue with focus on non-metallic inclusions and forming. Rakenteiden Mekaniikka, 50(3):146-152, 2017. URL: https ://doi .org/10.23998/rm.65048.

[184] Roger Rabb. Väsyminen ja todennäköisyysteoria. ISBN: 978-952-62-1639-3. Oulun yliopisto Suomen Yliopistopaino Oy Juvenes Print, 2017.

[185] Tero Frondelius, Antti Mäntyä, Joona Vaara, Juho Könnö, Tom Andersson, Matti Lindroos, Tuukka Verho, and Anssi Laukkanen. Micromechanical modeling of the role of inclusions in high cycle fatigue damage initiation and short crack growth. In CAASE18 The Conference on Advancing Analysis 85 Simulation in Engineering. Nafems. 
[186] Christian Lönnqvist and Antti Mäntylä. Fracture mechanics approach to contact problems in medium speed diesel engines. CIMAC, 26th CIMAC World Congress on Combustion Engine, Bergen, NO, Jun 14-17, 2010, 2010.

[187] Jouko Hintikka. Kitkan ja kitkaväsymisen kokeellinen tarkastelu pallo-tasokosketuksessa, 2010. Master's thesis from Tampere University of Technology. URL: https://tut.finna.fi/Record/tutcat.196457.

[188] Janne Kortelainen. Koelaitteen kehittäminen kitkaväsymisen tutkimiseen taso-tasokosketuksessa, 2010. Master's thesis from Tampere University of Technology. URL: https://tut.finna.fi/Record/tutcat.195822.

[189] Arto Lehtovaara, C. Lönnqvist, and A. Mäntylä. A numerical model for the calculation of fretting fatique crack initiation for a smooth line contact. Tribologia, 29(1):7-16, 2010.

[190] Jussi Immonen, Arto Lehtovaara, and Christian Lönnqvist. Modelling of fretting fatigue cracking risk in shrink fit with wavy surfaces. In 14 th Nordic Symposium on Tribology, Nordtrib 2010, Storforsen, Sweden, Luleå University of Technology, 2010 .

[191] Jouko Hintikka, Arto Lehtovaara, and Christian Lönnqvist. Effect of start-up schemes and amplitude of tangential motion on friction behavior in fretting point contact. Tribology International, 44(11):1535-1543, 2011.

[192] A Lehtovaara, R Rabb, and A Pasanen. Modelling and evaluation of the fretting fatigue cracking risk in smooth spherical contacts. Tribology International, 44(11):1526-1534, 2011.

[193] Antti Mäntylä, Juho Könnö, Jouko Hintikka, and Arto Lehtovaara. Fretting analysis methodology for the connecting rod of medium speed diesel engine. 7th International Symposium on Fretting Fatigue, Oxford, UK, 2013.

[194] Jouko Hintikka, Arto Lehtovaara, and Antti Mäntylä. Fretting fatigue and friction of quenched and tempered steel in dry contact with aluminum bronze. Wear, 308(1):155-165, 2013.

[195] Janne Juoksukangas, Arto Lehtovaara, and Antti Mäntylä. The effect of contact edge geometry on fretting fatigue behavior in complete contacts. Wear, 308(1):206$212,2013$.

[196] Janne Juoksukangas, Arto Lehtovaara, and Antti Mäntylä. Development of a complete contact fretting test device. Proceedings of the Institution of Mechanical Engineers, Part J: Journal of Engineering Tribology, 227(6):570-578, 2013.

[197] J Juoksukangas, A Lehtovaara, and A Mäntylä. Response to discussion with da hills et al., concerning the article "development of a complete contact fretting test device" by j juoksukangas et al., 2014.

[198] Tomi Koivula. Kuulapuhalluksen ja typetyksen vaikutus nuorrutusteräksen kitkaväsymiseen, 2013. Master's thesis from Tampere University of Technology. URL: https://tut.finna.fi/Record/tutcat. 234892. 
[199] Jouko Hintikka, Arto Lehtovaara, and Antti Mäntylä. Non-coulomb friction in gross sliding fretting conditions with aluminium bronze against quenched and tempered steel. Tribology International, 79:151-161, 2014.

[200] Mattia Pujatti, Mitja Suhadolc, and Daniel Piculin. Fretting-initiated fatigue in large bore engines connecting rods. Procedia Engineering, 74(Supplement C):356 - 359, 2014. XVII International Colloquium on Mechanical Fatigue of Metals (ICMFM17). URL: https://doi.org/10.1016/j.proeng.2014.06.279.

[201] Jouko Hintikka, Arto Lehtovaara, and Antti Mäntylä. Fretting-induced friction and wear in large flat-on-flat contact with quenched and tempered steel. Tribology International, 92:191-202, 2015.

[202] Antti Mäntylä, Juho Könnö, Jouko Hintikka, and Arto Lehtovaara. Dynamic contact analysis for medium speed combustion engines. 8th International Symposium on Fretting Fatigue, Brasilia, Brazil, 2016.

[203] Sami Holopainen, Janne Juoksukangas, Reijo Kouhia, Arto Lehtovaara, and Timo Saksala. An investigation of fatigue damage development under complete contact fretting test conditions. Rakenteiden mekaniikka, 49(3):151-159, 2016.

[204] Janne Juoksukangas, Arto Lehtovaara, and Antti Mäntylä. Experimental and numerical investigation of fretting fatigue behavior in bolted joints. Tribology International, 103:440-448, 2016.

[205] J Juoksukangas, A Lehtovaara, and A Mäntylä. A comparison of relative displacement fields between numerical predictions and experimental results in fretting contact. Proceedings of the Institution of Mechanical Engineers, Part J: Journal of Engineering Tribology, 230(10):1273-1287, 2016.

[206] Jouko Hintikka. Fretting Induced Friction, Wear and Fatigue in Quenched and Tempered Steel. Tampere University of Technology. Publication. Tampere University of Technology, 62016.

[207] Jouko Hintikka, Arto Lehtovaara, and Antti Mäntylä. Normal displacements in non-coulomb friction conditions during fretting. Tribology International, 94:633639, 2016.

[208] T. Kuivaniemi. System to reduce the fretting in a bolt-joint (especially for a crankshaft-counterweight structure), March 32016 . WO Patent App. PCT/FI2014/050,660. URL: https://www.google.fi/patents/ W02016030569A1?cl=en.

[209] Jouko Hintikka, Arto Lehtovaara, and Antti Mäntylä. Third particle ejection effects on wear with quenched and tempered steel fretting contact. Tribology Transactions, 60(1):70-78, 2017.

[210] J Juoksukangas, A Lehtovaara, and A Mäntylä. Applying the digital image correlation method to fretting contact for slip measurement. Proceedings of the Institution of Mechanical Engineers, Part J: Journal of Engineering Tribology, 231(4):509-519, 2017. 
[211] Janne Juoksukangas. Modelling and Experimental Analysis of Fretting Fatigue in Complete and Bolted Contacts. Tampere University of Technology. Publication. Tampere University of Technology, 52017.

[212] Jouko Hintikka, Arto Lehtovaara, Tero Frondelius, and Antti Mäntylä. Tangential traction instability in fretting contact below fully developed friction load. Rakenteiden Mekaniikka, 50(3):175-178, 2017. URL: https://doi.org/10.23998/rm. 65105.

[213] Jouko Hintikka, Jouko Juoksukangas, Arto Lehtovaara, Tero Frondelius, and Antti Mäntylä. Non-idealities in fretting contacts. Rakenteiden Mekaniikka, 50(3):171174, 2017. URL: https://doi.org/10.23998/rm.64886.

[214] Antti Mäntylä, Jussi Göös, Anton Leppänen, and Tero Frondelius. Large bore engine connecting rod fretting analysis. Rakenteiden Mekaniikka, 50(3):239-243, 2017. URL: https://doi.org/10.23998/rm.64914.

[215] A. Mäntylä. Method for preventing fretting, tool for deforming a contact surface and use of the tool, August 23 2017. EP Patent 3,063,420. URL: https://www. google.fi/patents/EP3063420B1?cl=en.

[216] Verner Nurmi, Jouko Hintikka, Mari Honkanen, Janne Juoksukangas, Antti Mäntylä, Tero Frondelius, Arto Lehtovaara, and Minnamari Vippola. Microstructural characteristics of fretting scars. SCANDEM 2018. URL: http://www.cen. dtu.dk/english/scandem-2018.

[217] Joona Vaara. Simplified vibroacoustic analysis of a viscoelastic sandwich panel structure, 2013. Master's thesis from University of Oulu. URL: http://urn.fi/ URN : NBN : fi : oulu-201309261736.

[218] Carlo Pestelli, Hannu Tienhaara, and Moreno Almerigogna. Machinery noise and vibration sources. Encyclopedia of Maritime and Offshore Engineering.

[219] Pasi Halla-aho, Antti Mäntylä, Tero Frondelius, Tommi Helander, and Juha Hautala. Counterweight measurements device development. Rakenteiden Mekaniikka, 50(3):318-322, 2017. URL: https://doi.org/10.23998/rm.65050.

[220] Jukka Aho and Tero Frondelius. Analyzing 3 TB field measurement data set. Rakenteiden Mekaniikka, 50(3):224-228, 2017. URL: https://doi.org/10.23998/ rm. 64942 .

[221] Evgeniya Kiseleva, Juho Könnö, Niclas Liljenfeldt, Teemu Kuivaniemi, and Tero Frondelius. Topology optimisation of the in-line engine turbocharger bracket. $R a$ kenteiden Mekaniikka, 50(3):323-325, 2017. URL: https://doi.org/10.23998/ rm. 65071.

[222] Mikael Nyberg, Antti Mäntylä, and Tero Frondelius. Explosion simulation of pressurized components. Rakenteiden Mekaniikka, 50(3):198-200, 2017. URL: https://doi.org/10.23998/rm.65076.

[223] Marja Rapo, Jukka Aho, and Tero Frondelius. Natural frequency calculations with JuliaFEM. Rakenteiden Mekaniikka, 50(3):300-303, 2017. URL: https://doi.org/ $10.23998 / \mathrm{rm}$. 65040 . 
[224] Tero Frondelius and Jukka Aho. JuliaFEM — open source solver for both industrial and academia usage. Rakenteiden Mekaniikka, 50(3):229-233, 2017. URL: https: //doi.org/10.23998/rm.64224.

[225] Marja Rapo, Jukka Aho, Hannu Koivurova, and Tero Frondelius. Implementing model reduction to the JuliaFEM platform. Rakenteiden Mekaniikka, 51(1):36-54, 2018. URL: https://doi.org/10.23998/rm.69026.

[226] Joona Vaara and Juho Könnö. Modeling asymmetric cyclic plastic hysteresis of nodular cast iron materials. In Proceedings of the XII Finnish Mechanics Days, 2012.

[227] Reijo Kouhia. Preface, plenary abstracts and the program of the RM50-seminar. Rakenteiden Mekaniikka, 50(3):i-xv, 2017.

Tero Frondelius, Hannu Tienhaara

Wärtsilä

Järvikatu 2-4

65100 Vaasa

tero.frondelius@wartsila.com, hannu.tienhaara@wartsila.com

Tero Frondelius, Mauri Haataja

University of Oulu

Erkki Koiso-Kanttilan katu 1

90014 OULUN YLIOPISTO

tero.frondelius@oulu.fi, mauri.hataja@oulu.fi 